\title{
Mekke Evlerinin Satışı ve Kiralanmasına Dair Rivayetler ve Değerleri*
}

\section{Rumors of the Sale and Rental of Mecca Houses and Their Value}

\section{Hasan Eryılmaz}

Öğretmen, Hasbekli Hafız Mü'min Akan AİHL

Teacher, Hafiz Mu'min Akan from Hasbek, ECHR

Kayseri / Turkey

hasaneryilmaz85@gmail.com | https://orcid.org/0000-0001-5343-6981

Article Type / Makale Tipi

Research Article / Araştırma Makalesi

DOI: $10.33420 /$ marife.1009350
Article Information / Makale Bilgisi

Received / Geliș Tarihi: 13.10.2021

Accepted / Kabul Tarihi: 13.12.2021

Published / Yayın Tarihi: 30.12.2021

Cite as / Atıf: Eryılmaz, Hasan. "Mekke Evlerinin Satışı ve Kiralanmasına Dair Rivayetler ve Değerleri". Marife 21/2 (2021): 909-934. https://doi.org/10.33420/marife.1009350

Plagiarism / Intihal: This article has been reviewed by at least two referees and scanned via a plagiarism software. / Bu makale, en az iki hakem tarafından incelendi ve intihal içermediği teyit edildi.

Copyright / Telif Hakkl: "This article is an open access article distributed under the terms and conditions of the Creative Commons Attribution-NonCommercial-NoDerivatives 4.0 (CC BY-NC-ND 4.0) International License." / "Bu makale Creative Commons Alıntı-GayriTicari-Türetilemez 4.0 (CC BY-NCND 4.0) Uluslar arası Lisansı altında lisanslanmıştır."

Ethical Statement / Etik Beyan: *This study is based on the master's thesis titled "The source value of the hadiths about the sale and renting of Meccan houses and the approach of the fiqh sects to these hadiths", which we completed in 2018. / Bu çalışma 2018 yılında tamamladığımız "Mekke Evlerinin Satışı ve Kiralanmasına Dair Hadislerin Kaynak Değeri ve Bu Hadislere Fıkhî Mezheplerin Yaklaşımı" başlıklı yüksek lisans tezi esas olarak hazırlanmıştır. 


\section{Mekke Evlerinin Satışı ve Kiralanmasına Dair Rivayetler ve Değeri}

\section{Özet}

İnsanın yeryüzüne gönderildiği andan itibaren mukaddes bir coğrafya kabul edilen Harem bölgesi, Kâbe'nin Hz. Ibrâhim tarafindan inșasıyla birlikte dini yașantıda daha mühim bir yer bulmuștur. Son peygamber Hz. Muhammed'in bu torpraklardan seçilmesi ve Kur'an'ın diliyle efdaliyetine işaret edilmesi harem bölgesinin kutsiyetini perçinlemiştir. Bu saydıklarımızın yanısıra Hz. Peygamber'e dayandırılan ciddi bir hadis müktesebatı da bulunmaktadır. Mekke ile ilgili rivayet malzemelerine bakıldığında bir kısmının bölgenin efdaliyetine ilişkin olduğu gözlemlenirken diğer bir kısmının ise Mekke'ye özgü birtakım uygulamaları barındırdığı söylenebilir. Öyle ki bölgeye has uygulamalar, süreç içerisinde sadece Mekke özelinde bir fikıh literatürünün doğmasına da vesile olmuștur. Söz konusu literatüre konu olan hususlardan birisi de Mekke evlerinin satışı ve kiralanmasının caiz olup olmaması ile ilgilidir. Kaynaklarda bu konuya ilișkin cevaz ve nehy ifade etmek üzere iki farklı rivayet grubu yer almaktadır. Konuyla ilgili birbirine zıt hususların hadis diliyle aktarılmış olması müctehid imamlar arasında da bazı değiş̧ik yorum ve yaklaşımlara sebebiyet vermiştir. Kuşkusuz Mekke evleri çerçevesinde zuhur eden bu yorum ve yaklaşımların boyutlarını sadece $\mathrm{Hz}$ Peygamber'e nispet edilen hadisler olușturmamaktadır. Mescid-i Harâm'ın orada bulunan ve bulunmayan bütün Müslümanlar nazarında söz konusu olan statüsü ve bu statüye işaret eden Hacc sûresinin yirmi beșinci âyeti de anlaşmazlıkların diğer bir yüzünü teșkil etmektedir. Nitekim Hudeybiye Antlaşması sonrasındainen bu âyet, bir taraftan Kâbe'nin bütün Müslümanların ortak değeri olduğu mesajını verirken, diğer taraftan Mescid-i Harâm etrafinda bulunan evler ile ilgili fikhî değerlendirmelerdeki farklllıkların derinleşmesine de sebep olmuştur. Mekke'nin fethedilme șekli konusunda ilim ehli arasındaki anlayış farklllıkları da konunun ayrı bir yüzünü teşkil etmektedir.

Bu makale, yukarıda da zikri geçtiği üzere Mekke evlerinin satışı ve kiralanması konusundaki rivayetlerin kaynak değeri ve yorumlanmasını konu edinmektedir. Çalışma, ilgili rivayetlerin dört büyük fikı mezhebi tarafindan yorumlanması ile sınırlandırılmıştır. Bu çalışma ile maksadımız hadislerin yorumlanmasında mezhepler arası farklılığı gözler önüne sermektedir. Her mezhebin kendisine ait bir düşünce sistematiği ve literatür birikimi olabilmektedir. Bu müktesebat farklliğg neticesinde aynı malzeme üzerinden farklı sonuçlara ulaşılması mümkündür. Bu durum Mekke evlerinin satıșı ve kiralanması ile ilgili fikhî çıkarımlarda da kendisini göstermektedir. Burada dikkat çekici olan ise imam Şâfîi dışında üç mezhep imamının Mekke evlerinin satışı ve kiralamasını câiz görmemeleridir. Çünkü onlar zaman içerisinde evlerin fâhiş fiyatlar ile satış ve kiralanması neticesinde hac ibadetinin doğal olarak engellenebileceği endişesini taşımaktadırlar. Bugüne gelindiğinde Mezhep imamlarının söz konusu endișesini haklı çıkaran birtakım sıkıntıların varlğı̆ı görmemek mümkün değildir. Üstelik bu durum sadece konaklama imkânı sağlayan evlerle sinırlı kalmayarak genel anlamda hac ibadeti ile ilgili her hususta kendini göstermektedir. Öyleki bu sıkıntılar talep edilen fâhiş fiyatlar eliyle müminleri ömürleri buyunca farz olan hac ibadetinden mahrum edebilecek bir seviyede kendini gösterebilmektedir. Bu çalışmada, adeta multimilyoner ibadetine dönüșme sürecine giren ve yüksek karlar elde etme aracı olarak kullanılan uygulamaların aksine bütün Müslümanların ibadetlerini eșit bir șekilde yapabilecekleri alternatif bir model arama konusunda farkındalık oluşturmak amaçlanmıștır. Aynı şekilde hadislerin yorumlanmasına dikkat çekici bir örnek üzerinden bakma imkânı bulunan bu çalışma, rivayetlerin doğurabileceği sonuçları dikkate alarak yorumlanması gerektiği konusunda bir fikir vermesi bakımından da önem arz etmektedir.

Anahtar Kelimeler: Hadis, Mekke, Mescid-i Harâm, Mezhep, Satış.

\section{Narrations on Selling and Renting the Houses in Makkah and Their Credibility}

Summary

The Haram region has been important since mankind was sent to earth. The building of Ka'ba by Abraham there also made it a very important place for religious life. The fact that the last of the prophets Muhammad was from there and the language of the Qur'an was the language of this area strengthened the importance of it. Along with these, a serious number of hadith narrations chained 
back to prophet Muhammad also exist about the significance of that area. When those narrations are examined, it is seen that while some of them are about the significance of the region, some are about practices specific to Makkah. It was true to an extent that after a while, a jurisprudential literature specific to Makkah was born. One of the topics that were discussed in that literature was whether selling or renting the houses in Makkah was permissible or not. In the sources, there are two different views, one is in favor of selling and renting, one is against. These opposite views were both came down to us in hadith form and this fact led jurists to follow different interpretations and approaches. Of course, the narrations followed back to the prophet himself did not compose the framework of the discussions on the houses in Makkah. The status of Masjid al-Haram in the eyes of all Muslims and the $25^{\text {th }}$ verse of the Surah Hajj that points at this status represents the other part of the discussion. For the said verse which was revealed after Hudaybiyyah Peace Treaty caused the existing different opinions to move away from each other even further and at the same time declared the Ka'ba to be a common value of all Muslims. The difference of opinion between the scholars about the way Makkah was conquered also represents another aspect of the whole discussion on the houses of Makkah.

This article is interested in the evaluation and the interpretation of the narrations about selling and renting houses in Makkah. The study is limited to the evaluation of the narrations according to the four major fiqh schools. The aim of the study thus is to show the differences between the fiqh schools in the interpretations of the narrations. Every madhab/school have their thought system and literature. Due to these differences, they may reach different results by looking at the same narrations. An example of this is seen in their views about selling and renting the houses in Makkah. What is interesting here is that the three founding Imams of three major madhabs claimed that it was not permissible to sell or rent the houses in Makkah while only Imam Shafi'i claimed otherwise. The reason behind the decision of the three was that in time, with an exorbitant rise in the prices of the houses in Makkah for both renting and selling, the practice of Hajj could be in danger. Today, some of the economic issues in the region seem to prove their concern right. This situation is not limited to the housing problem during Hajj but to all aspects of the practice. In so much that those extraordinary prices for everything during the Hajj period strip the Muslims of their possibility to realize their goal of visiting the holy places and completing their religious duty. One of the aims of this study is to raise awareness about the "Hajj Market" that is slowly becoming a huge problem for Muslims since it only allows the extremely rich to perform this obligatory religious duty and search for an alternative model. It also provided us with an opportunity to see the differences in the interpretations of ahadith through an interesting example. Another important outcome was that we came to see the importance of the consideration of the possible outcomes of the narrations in the future should be a reason to follow a specific interpretation among others.

Keywords: Hadith, Makkah, Masjid al-Haram, Madhab, Sale.

\section{Giris}

Günümüzde hadis ilminin en önemli problemleri arasında rivayetlerin anlaşlıp yorumlanması meselesi gelmektedir. Bağlamından kopmuş bir vaziyette karşlaştı̆̆ımız hadislerin hangi amaçla söylendiğini tespit etmek her zaman kolay olmamaktadır. Diğer taraftan bu zorluk Hz. Peygamber'in söylediği bir sözü hangi vasıfla söylediğini tam olarak belirleyememekten de kaynaklanabilmektedir. Hz. Peygamber'in bir sözünün nübüvvet, müfti yahut hâkim kimliklerinden hangisiyle söylendiği ilim adamları arasında münakaşa konusu olmuştur. Bu çalışmada da âlimler arasında ihtilafa neden olan, ilk etapta günümüz şartlarıyla düşündüğümüzde anlaşılması zor gibi görülen Mekke evlerinin satışı ve kiralanmasına izin vermeyen hadisler ele alınmıştır. Ancak tartışmanın boyutlarını sadece hadisler oluşturmamaktadır. Mescid-i Harâm'ın orada bulunan ve bulunmayan bütün Müslümanlar nazarında söz konusu olan statüsü ve bu statüye işaret eden Hacc sûresinin yirmi beşinci âyeti de anlaşmazlıkların diğer bir yüzünü teşkil etmektedir. Hudeybiye Antlaşması sonrasında indiği kabul gören Hac Suresi 25. âyeti bir taraftan Kâbe'nin bütün Müslümanların ortak değeri olduğu mesajını verirken di- 
ğer taraftan Mescid-i Harâm etrafında bulunan evler hakkında da farklı birtakım fıkhî değerlendirmelerin yolunu açmıștır. Öte yandan bu âyete paralel olarak güvenilir kaynaklarda pek çok da rivayet kaydedilmiştir. Bunlara ilaveten Mekke'nin fethedilme şekli konusunda ilim ehli arasındaki ihtilaflar da konunun ayrı bir boyutunu oluşturmaktadır. Bu çalışmada meselenin farklı açllarına işaret edilmekle birlikte, esas olarak Mekke evlerinin satışı ve kiralanmasına ilişkin hadislere yer verilecek, hadislerin kaynak değeri ve mezheplerin bu hadisleri nasıl anladıklarına dair görüşleri ele alınacaktır.

Çoğu Müslümanın belki de hiç duymadığı ve hatta ilim çevrelerinden pek azının vakıf olduğu Mekke evlerine dair rivayetler, taşıdığı amaç bakımından bölgenin kutsiyetini benimsemiş bütün Müslümanları ilgilendiren bir meseledir. Zira hac farizası ve umre ziyareti Kitap ve Sünnetle tescillenmiş tüm inanların ortak bir değeridir. Bu durum haccın ve umrenin herkes tarafından kolaylıkla yerine getirilebilecek bir ibadet olarak algılanmasını ve bu amacı gerçekleştirecek şekilde hac ve umre yapılanmasının sağlanmasını gerektirmektedir. Hadislerden ve âlimlerin çoğunun görüşlerinden anlaşıldığına göre hac ibadetinin birtakım kimseler tarafından ranta çevrilmesine fırsat verilmemesi gerekmektedir. Şayet haksız kazanç zihniyetine izin verilmesi durumunda, oranın kutsiyetine gönül vermiş mü'minlerin Allah'ın evini ziyaretten mahrum olması gibi nahoş bir durumun gündeme gelmesi kaçınılmaz olacaktır. Nitekim mevcut uygulamalarda bölgenin kutsiyeti göz ardı edilerek özellikle maddi durumu olmayan müm'inler ile hac ve umre farizası arasına giren birtakım engeller, dünya Müslümanlarının ortak sıkıntıları arasında sayılabilmektedir. Hâlbuki Suud yönetiminin bütün Müslümanları olumsuz etkileyen harem bölgesi ile ilgili tasarruflarına alternatif olarak rivayet malzemelerinde çeşitli uygulamalara rastlanılabilmektedir. Bu yönüyle ümmetin salahiyeti ve hac farizasının herkes için daha ulaşılabilir olması adına hadis müktesebatının ışığında farklı çözümlerin üretilebileceği âşikardır. Daha önce hiçbir akademik çalışmada bulamadığımız bu çalışma ile Hz. Peygamber, Hz. Ebû Bekir ve Hz. Ömer zamanındaki uygulamayı gündeme getirmek suretiyle bir bilincin oluşması ve en azından bu meselenin Müslümanların gündeminde yer alması hedeflenmektedir.

Kaynaklarda Mekke evlerinin satışına ve kiralanmasına izin veren ve nehyeden olmak üzere iki farklı rivayet malzemesi yer almaktadır. Bu hadislerin fıkıhçılar tarafından nasıl anlaşıldığına geçmeden önce bu farklı rivayetlerin iki grup halinde zikredilmesi konunun anlaşılması için daha uygundur.

\section{Mekke Evlerinin Satışını, Kiralamasını ve Mirasını Reddeden Riva- yetler}

Hadis 1:

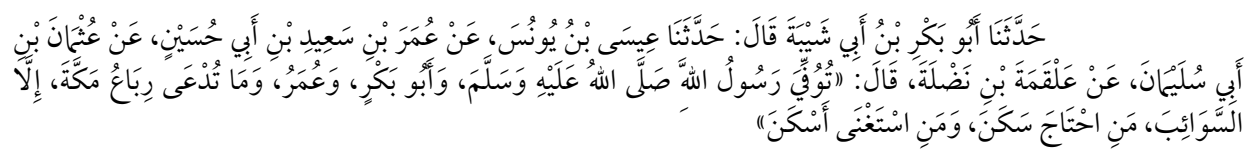

Alkame bin Nadle (r.a)'den rivayet edildiğine göre o şöyle demiştir: "Mekke evlerine ancak sevâib (yâni oturanların mülkü olmayıp ihtiyaç sahihlerine 
terkedilmiş olarak) denile geldiği halde Hz. Peygamber, Hz. Ebû Bekir ve Hz. Ömer vefat ettiler. Kim (meskene) muhtaç ise (Mekke evlerinde) oturur ve kim muhtaç değil ise ihtiyâcı olana (bedelsiz olarak) bırakır." ${ }^{1}$

İlk hadisimiz Alkame b. Nadle rivayeti olarak bilinmektedir. ${ }^{2}$ Mekke evlerinin satıșı ve kiralanmasının yasak olduğunu ifade eden rivayetler içerisinde Kütübü Sitte müelliflerinin tahriç ettiği iki hadisten biri olmak üzere Sünen-i İbn Mâce'de "Mekke Evlerinin Ücreti" bâb bașlı̆̆ ile rivayet edilmiștir. İbn Mâce șarihlerinden İbn Zenceviye (ö. 251/865) ${ }^{3}$ bu rivayeti "Zorla Toprak Fethi" bâbı ile nakletmektedir. Bu rivayet aynı lafız ve isnad ile İbn Ebî Şeybe (ö. 235/849), Taberânî (ö. 360/970) ve Dârekutnî (ö. 385/995) tarafından da nakledilmiștir. ${ }^{4}$ Hadis, "Mu'cemu's-Sahâbe" ve "Ma'rifetü's Sahâbe"de ise Müsedded kanalıyla yer alırken5, Fâkihî (ö. 272/885), Ezrakî (ö. 250/864), Tahâvî (ö. 321/933) ve Dârekutnî (ö. 385/995) rivayetlerinde ise Yahyâ b. Süleym'den ${ }^{6}$ nakledilmiştir.

Buhârî (ö. 256/869) aynı konuyu Hac suresi 25. âyetten esinlenerek "Mekke evlerinin satışı, kiralanması, mirası ve bütün insanların orada eşit olduğu" bâbı ile Alkame hadisinin aksine cevaz bağlamında ele almıştır. Onun bu tavrından hareketle ilgili rivayeti zayıf telakki ettiği yönünde yorumlar yapılmıștır. ${ }^{7}$ Misbâhu'z Zücâce'de rivayetin İbn Mâce dıșında diğer Kütüb-ü Sitte eserlerinde bulunmadığı, ancak Müslim'in şartlarını taşıdığı belirtilmiştir. ${ }^{8}$ İbn Hacer (ö. 852/1449) ise, is-

${ }^{1}$ Ebû Abdillâh Muhammed b. Yezîd Mâce el-Kazvînî, es-Sünen, thk. Şuayb Arnavut (y.y: Dâru'l Risaleti'l Âlemiyye, 2009), "Menâsik", 102.

2 Ebü'l-Kāsım Süleymân b. Ahmed et-Taberânî, el-Mu'cemü'l Kebîr, thk. Hamdî b. Abdülmecid es-Selefî (Kahire: Mektebetü'l İbn Teymiyye, 1994/1415), 18/ 8 (7).

${ }^{3}$ Ebû Ahmed Humeyd b. Muhlid İbn Zenceviye, el-Emvâlü'l İbn Zenceviye, (Suud: Merkez-ü el-Melik Faysal li'l Buhûs ve'd Dirasâti'l İslâmiyye, 1986/406), 1/204 (244).

${ }^{4}$ Ebû Bekr Abdürrezzâk b. Hemmâm b. Nâfi' es-San'ânî, el-Musannef, thk. Habîbu'r Rahman el-Azmî (Hindistan: Meclisü'l İlmî, 4103) 3: 331 (14693); Taberânî, Mu'cemi'l Kebîr, 18: 8 (7); Ebü'l-Hasen Alî b. Ömer b. Ahmed ed-Dârekutnî, esSünen, thk. Şuayb Arnavut. 5 Cilt. Beyrut: Müessestü'r Risâle, 2004, 4/14 (3019).

${ }^{5}$ Ebü'l-Hüseyn Abdülbâkī b. Kāni' b. Merzûk el-Ümevî, Mu'cemü's Sahâbe (Medine: Mektebü'l Gurâbâi'l Eseriyye, 1418), 2/287 (819); Ebû Nuaym Ahmed b. Abdillâh b. İshâk el-İsfahânî, Ma'rifetü's Sahâbe, thk. Adil b. Yûsuf el-Azâzî (Riyad: Dâru'l Vatan-i li'n Neşr, 1998/1419), 4/2180 (5466).

${ }^{6}$ Ebû Abdillâh Muhammed b. İshâk el-Fâkihî, Ahbâru Mekke, (Beyrut: Dâru'l Hadar, 1414), 3/214 (2047); Ebü'l-Velîd Muhammed b. Abdillâh b. Ahmed b. Muhammed el-Ezrâkī, Ahbâru Mekke, thk. Rüşdî Es-Salih (Beyrut: Dâru'l Endülüs li'n Neşr, t.y), 2/163; Ebû Ca'fer Ahmed b. Muhammed b. Selâme el-Ezdî el-Hacrî el-Mısrî et-Tahâvî, Şerh-u Meâni'l Âsar (Medine: Âlemü'l Kütüb, 1994/1414), 4/49 (5666); Dârekutnî, es-Sünen, 4/ 14 (3019)

7 Ebü'l-Fazl Șihâbüddîn Ahmed b. Alî b. Muhammed el-Askalânî, Fethu'l Bârî (Beyrut: Dâru'l Ma'rife, 1379), 3/450.

${ }^{8}$ Ebü'l-Abbâs Şihâbüddîn Ahmed b. Ebî Bekr el-Bûsîrî, Misbahu'z Zücâce fî Zevâid-i İbn Mâce (Beyrut: Dâru'l Arabî, 1403), 3/216. 
nadında kopukluk ve irsal olduğuna kanaat getirmiştir. ${ }^{9}$ Rivayeti mutemed bulan isimlerden birisi Sindî’dir (ö. 1138/1725). Ona göre hadis bu şekilde rivayet edildiğinde hüccet vasfı taşımaktadır. ${ }^{10}$ Öte yandan Elbânî (ö. 1420/1999), rivayeti İbn Mâce'nin zayıflarını topladığı eserinde anarak onu zayıf bulduğunu ima etmiştir. ${ }^{11}$ Hadisin sıhhati ile ilgili tartışmaların yoğunlaştığı en önemli unsur ise rivayetin isnad edildiği Alkame b. Nadle'nin kimliğidir. Zira kaynaklarda onunla ilgili farklı kanaatlere yer verilmiştir. Örneğin Yahyâ b. Maîn (ö. 233/847), İbn Mende (ö. 395/1004), Beyhakî (ö. 458/1065) ve Demirî (ö. 808/1405) gibi isimler Alkame b. Nadle'nin sahâbe olmadığı görüşündedirler. ${ }^{12}$ Buna karşın İbn Hibbân (ö. 354/965), Askerî (ö. 395/1004) ve Ebû Nuaym (ö. 430/1038) ise onun sahâbeden olduğu konusunda ittifak etmişlerdir. ${ }^{13}$ Yine İbn Ebî Hâtim (ö. 327/938), Alkame b. Nadle hakkında babasına sorulduğunu, babasının ise bilmiyorum dediğini aktarmiş, ancak ona isnad edilen rivayeti "Mürseller" isimli eserinde tahriç etmiştir. ${ }^{14}$ İbn Ebî Nuaym (ö. 430/1038), onun doğru bir kimse olduğunu ve Firyâbî’nin (ö. 301/913) onunla çelişmediğini ifade etmiştir. ${ }^{15}$ Zehebî (ö. 748/1347), Osman b. Ebî Süleyman'dan başka kimsenin ondan rivayet etmediğini bildirmiştir. ${ }^{16}$ Ebû'l Kasım Begavî (ö. 317/929), onun sahâbe mi tabiin mi olduğunu bilmediğini ifade etmiştir. İbn Hacer (ö. 852/1448) ise sahâbe sözünün yanlış olduğunu ancak Alkame b. Nadle'nin tabiinin küçükleri arasında makbul olduğunu iddia etmektedir. ${ }^{17}$ Öte yandan İbn Abdülber'in (ö. 463/1070) onun için sahâbe dediği de rivayet edilmiştir. ${ }^{18}$ Çağdaş Hadis âlimlerinden Şuayb Arnavut, İbn Mâce'ye yazmış olduğu şerhte Alkame b. Nadle'nin sahâbe olduğu iddiasının gerçeği yansıtmadığını, onun

9 İbn Hacer el-Askalânî, Fethu'l Bârî, 3/450.

${ }^{10}$ Ebü'l-Fidâ' İmâdüddîn İsmâîl b. Şihâbiddîn Ömer b. Kesîr, Câmi'u'l Mesânîd ve's Sünen (Beyrut: Dâru'l Hadr, 1998/1419), 6/284.

11 Muhammed b. Muhammed. b. Süleyman er-Rûdânî, Cem'u'l Fevâid min Câmiu'l Usul (Beyrut: Mektebet-ü İbn Kesir, t.y), 2/1998.

12 Ebû Zekeriyya Yahyâ b. Maîn, Min Kelam-i Ebû Zekeriya (Şam: Dâru'l Me'mun-i li't Türâs, t.y), 99; Ebû'l Hasan Ali b. Ebû'l Kerim İbnü'l Esir, Üsdü'l Gâbe (Beyrut: Dâru'l Fikr, 1994), 3/585; Ebû Muhammed Abdurrahman b. Muhammed İbn Ebî Hâtim, el-Îlel (y.y: Metâbi'u'l Hamîdî, 2006), 3/289.

${ }^{13}$ Muhammed b. Hibbân b. Ahmed b. Hibbân, es-Sikât, (Hindistan: Vüzerâtü'l Meârif li'l Hükûmeti'l Âliyeti'l Hindiyye, 1973), 3/315; Ahmed b. Ali b. Hacer Ebû Fadl elAskalânî, Tehzîbü't Tehzîb (Hindistan: Matbuatü’t Dâirati'l Mearifi'n Nizamî, 1908), $7 / 279$.

${ }^{14}$ Ebû Muhammed Abdurrahman b. Muhammed İbn Ebî Hâtim, el-Merâsil (Beyrut: Müessesetü'r Risale, 1397), 150.

15 Ebû Nuaym, Ma'rifetü's Sahâbe, 3/1793.

${ }^{16}$ Ebû Abdillâh Şemsüddîn Muhammed b. Ahmed ez-Zehebî, el-Ma'na fi'd Dûefâ (y.y: Mektebetü'ş Şamile, t.y), 2/441.

17 Ebü'l-Haccâc Cemâlüddîn Yûsuf b. Abdirrahmân el-Mizzî, Tehzîbü’l Kemâl fi Esmâi'r Rical (Beyrut: Müessesetü'r Risale,1980), 20/311.

${ }^{18}$ Ebû Abdillâh Alâüddîn Moğultay b. Kılıç el-Bekcerî, İkmâl-ü Tehzîbi'l Kemâl, (y.y: Fârûku'l Hâdîset-i lit'Tabâa, 2001) 9/273. 
tabiinden, hadisinin de mürsel olduğunu ifade etmektedir. Ravinin halinin net bir şekilde bilinmemesi gerekçesi ile ilgili hadisi zayıf olarak nitelemiştir. ${ }^{19}$ Hadisle ilgili buraya kadar aktardıklarımızdan ravinin sahâbeden olmadığı dolayısıyla rivayetinde bir inkıtânın olduğu düşüncesi ağırlık kazanmaktadır.

Hadis 2:

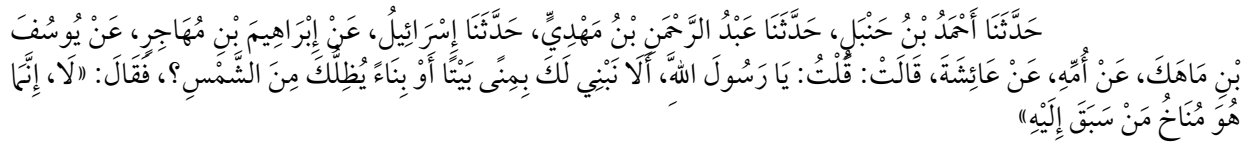

Hz. Âişe'den șöyle rivayet edilmiștir: “Ben, "Ey Allah’ın Resulü Mina'da senin için güneșten gölgelenebileceğin bir göz oda yahut bir bina yapsak ya." dedim. $O$, "Hayır, orası önce gelene aittir." buyurdu. ${ }^{20}$

Ebû Dâvud bu rivayete "Mekke Yasakları" konu başlığı ile temas ederken İbn Mâce ise "Mina'da konaklamak" bâb bașlığı ile iki defa zikretmiştir. ${ }^{21}$ Her iki rivayetin metninde de lafiz yönünden uygunluk bulunurken, isnadın tâbiinden sonraki nesillerinde değişik isimler göze çarpmaktadır. Rivayeti Kütüb-ü Sitte müelliflerinin dişında Ahmed b. Hanbel (ö. 241/855), Tahâvî (ö. 321/933) ve Ebû Ya'lâ (ö. 307/919) gibi müellifler de kaydetmişlerdir. ${ }^{22}$

Nesâî (ö. 303/915), bu hadis için "Hasen” değerlendirmesinde bulunmuştur. Ancak ne var ki onun dișında makbul yorum yapan pek kimse olmamıștır. Zira isnadında yer alan İbrâhim b. Muhâcir'in zayıf olduğu konusunda hadisçiler nazarında neredeyse bir ittifak olduğu söylenmiştir. ${ }^{23}$ Çağdaş muhaddislerden Şuayb Arnavut ${ }^{24}$ ve Nâsiruddin Elbânî ${ }^{25}$ de onu zayıf bulmaktadır.

Hadis 3:

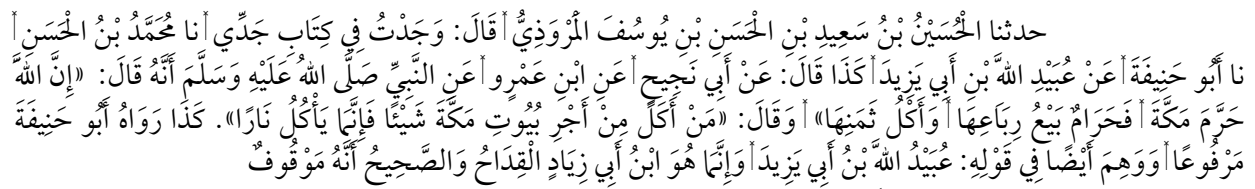

Ubeydullah b. Yezid'den rivayetle: “Allah Resulü şöyle buyurmuştur: Allah,

19 Ebû Abdillâh Muhammed b. Yezîd Mâce el-Kazvînî, es-Sünen, thk. Şuayb Arnavut (y.y: Dâru'l Risaleti'l Âlemiyye, 2009), 4/288.

20 Ebû Dâvûd Süleymân b. el-Eş'as b. İshâk es-Sicistânî, es-Sünen, thk. Şuayb Arnavut (Dâru'l Risâleti'l Âlemiyye,2009/1430), "Menâsik", 90.

21 İbn Mâce, "Menâsik", 52.

22 Ebû Abdillâh Ahmed b. Muhammed b. Hanbel, Müsned, thk. Şuayb Arnavut (Beyrut: Müessesetü'r Risâle, 2004), 42/349; Tahâvî, Şerh-u Meâni'l Âsâr, 4/50; Ebû Ya'lâ Ahmed b. Alî b. el-Müsennâ el-Mevsılî, Müsned, thk. H. Selim Esed (Şam: Dâru'l Me'mûn, 1984/1404), 8/16

23 Ebû Zekeriyya Muhyiddin Yahyâ b. Șerif en-Nevevî, el-Mecmu' Serhu'l Mühezzeb (y.y: Dâru'l Fikr, t.y), 9/250.

24 İbn Mâce, "Menâsik" 79 (1988)

25 Muhammed Nâsiruddin Elbânî, Dâifü Süneni't Tirmizî (Beyrut: el-Mektebetü'l İslâmî, 1991), 104. 
Mekke'yi haram kılmıştır. Onun evlerini satmak ve ürününü yemek haramdır. Kim Mekke evlerinin ücretinden bir şey yerse o ancak karnına ateş doldurmuş olur."26

Dârekutnî, "Kitâbü'l Büyû" isimli bâbda yer verdiği bu rivayetin ilk bölümünde yalnız kalmıştır. Özellikle "Ürününü yemek haramdır." ifadesi Mekke evleri ile ilgili rivayetlerin hiçbirinde bulunmamaktadır. Hadisin ikinci kısmı ise Abdullah b. Amr'dan Ezrakî, Fâkihî ve tekraren Dârekutnî tarafından tahriç edilmiştir. ${ }^{27}$ Dârekutnî, bu rivayetlerden birini Ebû Hanîfe'den merfu', diğerini ise Ubeydullah b. Ebî Yezid'den mevkûf olarak tahriç etmiştir. Bununla birlikte Ubeydullah b. Yezid'in asıl adının Ubeydullah b. Ebî Ziyad el-Kaddâh olduğu bilgisine yer vermiştir. Beyhakî, İbn Ebî Ziyad el-Kaddâh'tan gelen rivayetlerin mevkûf olduğunu tasdik etmiştir. ${ }^{28}$ el-Kaddâh, hadis münekkidleri tarafından "sikalara muhalif olmadlğında hasen"29, "hadiste zayıf"30 ve "rivayetleri münker"31 şeklinde değerlendirilmiştir. Elbânî de el-Kaddâh'ın bazen merfu' bazen de mevkûf rivayetlerde bulunduğu iddiası ile beşinci seviyeden zayıf bir ravi olduğunu söylemiştir. ${ }^{32}$

Hadis 4:

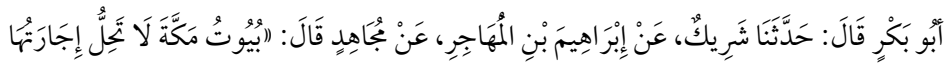

İbrâhim b. Muhâcir'den rivayet edildiğine göre Mücâhid, "Mekke evlerinin kiralanması helal olmaz." dedi. ${ }^{33}$

Rivayet, İbn Ebî Şeybe tarafından "Mekke Evlerinin satışının kerih görülmesi” bâb başlı̆̆ı ile kaydedilmiştir. ${ }^{34}$ İbn Ebî Şeybe, bu konuya Musannef'te oldukça geniş bir yer ayırmıştır. 0 , Mekke evleri ile ilgili rivayetleri, nehyeden, ruhsat veren ve diğer haberler olmak üzere üç başlık altında incelemiş olup, tekrarları ile birlikte toplam on beş rivayete yer vermiştir.

Hadis münekkidleri, hadisin ilk râvisi olan İbrâhim b. Muhâcir'e yönelik ciddi tenkitlerde bulunmuşlardır. Örneğin Yahyâ b. Said el-Kattan (ö. 198/813), Ahmed b. Hanbel ve Yahyâ b. Maîn (ö. 233/847) gibi otoriteler onun zayıf olduğunu söylemişlerdir. ${ }^{35}$ Nesâî de onu zayıf bulanlar arasındadır. ${ }^{36}$ İbn Âdî̀den (ö.

${ }^{26}$ Dârekutnî, es-Sünen, 4/12 (3015).

27 Ezrakî, Ahbâru Mekke, 2/163. Ayrıca Ebû Abdullah Muhammed b. İshâk elFâkihî, Ahbâru Mekke (Beyrut: Dâru'l Hadr, ts), 216; Dârekutnî, es-Sünen, 4/13 (3016).

${ }^{28}$ Ebû Bekr Ahmed b. el-Hüseyn b. Ali el-Beyhakî, Ma'rifetü's Sünen-i ve'l Âsar, Abdülmu'tî Emin Kal'acî (Kahire, Dâru'l Vefa, 1991), 8/214 (11687).

29 Ebû Abdurrahman Muhammed Nâsiruddin el-Elbânî, Sahih-i Ebî Dâvud el-Ümm, (Kuveyt: Müessesetü'l Gurâs-i li'n Neșr, 2002 /1423), 1/184.

${ }^{30}$ Elbânî, Sahih-i Ebî Dâvud el-Ümm, 5/234.

31 Ebû Zür'a Ubeydullah b. Abdilkerîm er-Râzî, ed-Duefâ li Ebî Zür'a er-Râzî, (Medine: İmâdetü'l Bahsi'l İlmî bi'l Câmiati'l İslâm, 1982), 2/634.

32 Ebû Abdurrahman Muhammed Nasiruddîn el-Elbânî, es-Silsiletü'l Ehâdisi'd Daîfe (Riyad: Dâru'l Meârif, 1992), 2/208.

33 Ebû Bekr Abdullāh b. Muhammed b. Ebî Șeybe, el-Musannef, thk. Kemâl el-Hût (Riyad: Mektebetü'r Rüşd, 1409), 3/329.

34 İbn Ebî Şeybe, el-Musannef, 3/330.

35 İbn Adî el-Cürcânî, el-Kâmil-u Duefâi'r Rical, 1/ 349; Ebû Zekeriyya Yahyâ b. 
365/975) gelen bir yorumda ise, "Bazı șeyleri birbirine katar ama bana göre İbrâhim el-Hicrî'den daha ehvendir" denmektedir. ${ }^{37}$ Bunların dışında sürekli isimleri karıștırdığı, ${ }^{38}$ onunla birlikte oğlunun da zayıf olduğ $\mathrm{u}^{39}$ onun olmadığı bazı rivayetlerin Müslim'in şartına göre sahih olabileceği ifade edilmiştir. ${ }^{40}$ Buna karşın kaynaklarda onunla ilgili müspet ifadelere de rastlanmaktadır. Mesela Yahyâ b. Said, Şube ve Hâkim'in hadis almak üzere ona müracaat ettiği, zikri geçen önceki görüşünün aksine Ahmed b. Hanbel'in ve Süfyân'ın onda bir beis görmedikleri zikredilmektedir. ${ }^{41}$ Ayrıca Buhârî̀nin de sika isimlerin ondan rivayette bulunduğu kaydı dikkate değerdir. ${ }^{42}$ Öte taraftan bazı hadisçiler tarafından sika olduğu da dillendirilmiştir. İbn Hacer el-Askalânî (ö. 852/1448), onun için "Sâlihu'l Hadîs" dendiği nakline yer verirken ${ }^{43}$ onun hafıza yönünden zayıf olduğu yorumunda bulunmuştur. ${ }^{44}$ Çağdaş hadisçilerden de benzer kayıtlara rastlanmaktadır. ${ }^{45}$

Tabakât kitaplarında hem müspet hem de menfi yorumlara muhatap olan İbrâhim b. Muhâcir'in esasen daha güçlü bir alternatifi bulunduğunda birtakım zafiyetleri nedeniyle rivayetlerinin terkedilebileceğini düşünmekteyiz. Bununla birlikte onda var olduğu düşünülen zafiyetin ise adalet yönünden ziyade hıfz yönünden kaynaklandığı kanaatindeyiz.

Hadis 5:

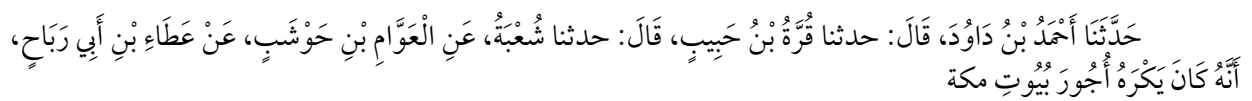

Ata b. Ebî Rebâh, "Evlerden (Mekke) kazanılan parayı kerih gördüğünü” rivayet etmiştir. ${ }^{46}$

İbn Ebî Şeybe, Atâ'dan gelen bu rivayete “Mekke Evlerinin Ücretini Kerih Görenler" bâb başlığı ile aynı metin, ancak farklı isnad zinciri ile iki kez yer vermiş-

Maîn, Târîh-u İbn Maîn, (Mekke: İhyâu’t Türâsi'l İslâmî, 1979), 3/538.

${ }^{36}$ Ahmed b. Şuayb en-Nesâî, ed-Duefâ-u ve'l Metrukûn, (Halep: Dâru'l Va'y, 1976), 11.

37 Ebû Ahmed Abdullāh b. Adî el-Cürcânî, el-Kâmil fî Duefâi'r Rical (Beyrut: Kütübi’l İlmiyye, 1997), 1/351.

${ }^{38}$ Elbânî, Silsiletü'l Ehâdîsi'd Daîfe, 3/448.

39 Ebû Fadl Muhammed b. Tahir İbni'l Kayserânî, Ma'rifetü't Tezkira fi'l Ehâdisi'l Mevzûa (Beyrut: Müessesetü'l Kütübi's Sekafe, 1985), 1/206.

40 Ebû Abdurrahman Muhammed Nâsiruddin el-Elbânî, İrvâu'l Galîl (Beyrut: Mektebetü'l İslâmî, 1985), 5/47.

41 Ebû Muhammed Abdurrahman b. Muhammed İbn Ebî Hâtim, Cerh ve Ta'dil (Beyrut: Dâru'l İhyâ-i Türasi'l Arabî, 1952), 2/133.

${ }^{42}$ Ebû Abdillâh Muhammed b. İsmâîl b. İbrâhim el-Cu'fî el-Buhârî, et-Târîhu'l Kebîr (Haydarâbâd, Dâiratü'l Meârifi'l Osmaniyye, t.y), 5/382.

43 İbn Hacer el-Askalânî, Tehzîbü't Tehzîb, 1/168.

${ }^{44}$ Elbânî, İrvâu'l Galîl, 3/373.

${ }^{45}$ Elbânî, Silsiletü'l Ehâdîsi'd Daîfe, 4/261.

46 Tahâvî, Şerh-u Meâni'l Âsâr, 4/49. 
tir. ${ }^{47}$ Tahâvî (ö. 321/933) "Mekke toprağının satılması ve kiralanması" isimliyle ele aldığı konu çerçevesinde toplam on dört rivayet nakletmiştir. ${ }^{48}$ Ata'dan rivayet olunan bu hadis, konunun haramlığına ișaret eden diğer bütün rivayetlerden farklı olarak, meseleyi kerahat bağlamında ele almaktadır.

Hadisin değerlendirilmesine gelindiğinde ise kaynaklarda şu yorumlara rastlanmaktadır. Yahyâ b. Maîn, rivayetin isnadında meçhul isimlerin bulunduğunu söylemiștir. ${ }^{49}$ Bunun aksine Aynî (ö. 855/1451) ise isnadda Buhârî̀nin hocalarından bazı isimlerin yer aldığına ve Ahmed b. Dâvud hariç bütün râvilerin sika olarak nitelendirildiğine yer vermiștir. ${ }^{50}$ Şeyh Elbânî de Aynî̀nin bu tespitini tasdik etmiştir. ${ }^{51}$ İbn Hacer ise rivayeti, mürseller, munkatılar ve mevkûflar bâbında zikrederek isnadındaki noksanlığa işaret etmiştir. ${ }^{52}$

Hadisin senedindeki bazı isimlerin sika kabul edilmesine rağmen ortada sağlıklı bir isnadın bulunmadığı kanaatindeyiz. Bu yönüyle İbn Hacer'in tespitlerini daha sağlıklı bulmaktayız.

Hadis 6:

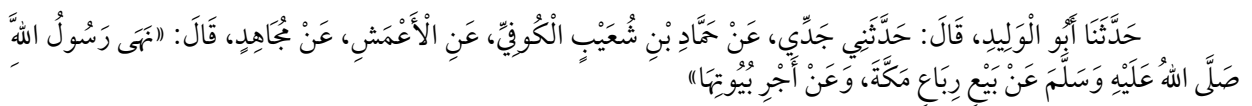

Mücâhid'den rivayetle: "Resulullah (s.a) Mekke evlerinin satışını ve kiralanmasını yasakladı."53

Abdürrezzak, Ezrakî ve Fakihî tarfından rivayet edilen hadis " kalıbı ile kaydedilmiștir. ${ }^{54} \mathrm{Bu}$ kalıpla gelen bütün rivayetlerin Mücâhid'den nakledildiği görülmektedir. Rivayetin isnadındaki isimler gözden geçirildiğinde râvilerden Hammâd b. Şuayb el-Kûfi'ye yönelik ağır ithamlar dikkat çekmektedir. Künyesi Eba Şuayb el-Kûfî olan râvi hakkında, "O bir șey değil, hadisini almayın",5556 "hadiste zayıftır",57 "haberleri değiştirip başka şekilde veriyor",58 "onun hadisini terk edin",59

47 İbn Ebî Şeybe, el-Musannef, $3 / 329$ (14681) (14690).

48 Tahâvî, Şerh-u Meâni'l Âsâr, 4/48.

49 Yahyâ b. Maîn, Min Kelâmi Ebî Zekeriyya, 66.

50 Ebû Muhammed Mahmud b. Ahmed Bedreddin el-Aynî, Nühabü'l Efkâr fi Tenkîhi'l Mebâni'l Ahbâr (Katar: Vizârâtü'l Evkâf-i ve'ş Şuûni'l İslâmiyye, 2008), $12 / 52$.

51 Elbânî, Silsiletü'l Ehâdîsi'd-Daîfe, 3/62.

${ }^{52}$ Ahmed b. Ali b. Hacer Ebû Fadl İbn Askalânî, İthâfü'l Mehere bi'l Fevâid (Medine: Mucemmâu'l Melik Fahd, 1994), 19/273.

53 Ezrakî, Ahbâru Mekke, 3/163.

${ }^{54}$ Abdürrezzâk, el-Musannef, 5/146 (9211); Fâkihî, Ahbâru Mekke, 3/219.

55 İbn Adî el-Cürcânî, el-Kâmil, 3/15.

${ }^{56}$ Ebû Abdirrahmân Ahmed b. Şuayb b. Alî en-Nesâî, ed-Duefâ ve'l Metrukûn, thk. Mahmud İbrâhim Zayid (Haleb: Dâru'l Va'y, 1396), 31.

57 İbn Ebî Hâtim, Cerh ve Ta'dil, 3/142.

${ }^{58}$ Cemâleddin Ebû'l Ferc Abdurrahman b. Ali el-Cevzî, ed-Duefâ ve'l Metrukûn, thk. Abdullah el-Kâdî (Beyrut: Dâru'l-Kütübi'l İlmiyye, 1985), 1/233.

59 Ebû Dâvud Süleyman b. Eş'as, Süelât-ü Ebî Ubeyd el-Âcurrî (Suudî Arabistan: 
"katımızda güçlü değil, zayıftır"60 ve "hakkında söylentiler vardır"61 gibi ifadelere kaynaklarda sıklıkla rastlanmaktadır. Rivayetin bu haliyle ileri derecede zayıf olduğu söylenebilir.

Hadis 7:

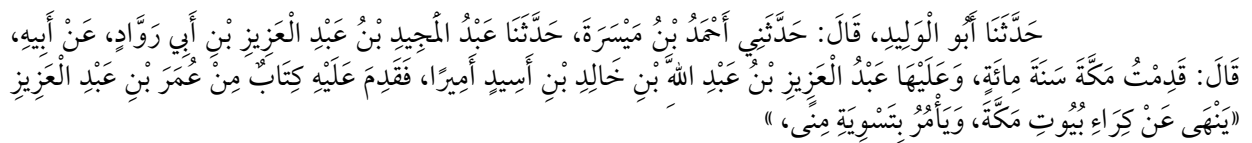

Abdülmecid b. Abdülaziz b. İbn Ebî Ravvâd, babasından şöyle rivayet etmiştir: "Hicrî yüz senesinde Mekke'ye geldim. Abdülaziz b. Abdullah'ın emir olduğunu gördüm. Orada iken Halife Ömer b. Abdülaziz'den bir mektup geldi. Halife, mektupta Mekke evlerinin kiraya verilmesini yasakliyor, Mina'nın tamir edilmesini emrediyor$d u^{\prime \prime} 62$

İbn Ebî Ravvad'ın babasından naklettiği bu rivayet aynı metinle Mansur b. Abdurrahman ${ }^{63}$, İbn Cüreyc ${ }^{64}$ ve Abdülkerim b. Ebî Muhârik ${ }^{65}$ olmak üzere pek çok değişik isimden de aktarılmaktadır. Bu rivayetlerin ortak özelliği isnad zincirinin iki ya da üç kişiden müteşekkil olmasıdır.

Kaynaklarda rivayetin isnad edildiği isim olan Abdülmecid b. İbn Ebî Ravvâd'ın, Ebâ Abdulhamid künyesi ile bilindiği ve bazı önde gelen muhaddislerce sika olarak tanımlandığı görülmektedir. ${ }^{66}$ Bunun yanı sıra silsilede bulunan diğer bir râvi Ahmed b. Meysere ise meçhul olarak değerlendirilmektedir. ${ }^{67}$ Hakkında son derece sınırlı bilgiler bulunan râvinin Süreyc b. Numan tarafından Ebû Salih künyesi ile nakillerine yer verilmiştir. ${ }^{68}$

Hadis 8:

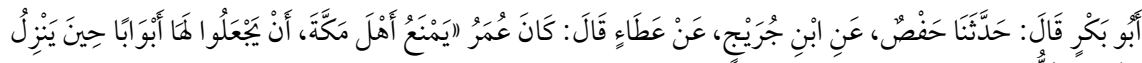

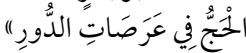

Ata'dan şöyle rivayet olunmuştur: “Ömer (r.a), Mekke halkına, ziyaretçilere

İmâdetü'l Bahsi'l İlmî bi'l Câmiati'l İslâmiyye, 1983), 139.

60 Ali b. Abdullah b. Cafer el-Medinî, Süelât-ü İbn Ebî Şeybe (Riyad: Mektebetü'l

Meârif, 1984), 78.

61 Buhârî, Târîhu'l Kebîr, 3/25.

62 Ezrakî, Ahbâru Mekke, 2/174.

63 İbn Zenceviye, Emvâlü'z Zenceviye, 1/207.

64 İbn Ebî Şeybe, el-Musannef, 3/330 (14683). Ayrıca bk. Ezrakî, Ahbâru Mekke, 2/13.

65 Ezrakî, Ahbâru Mekke, 2/163.

66 İbn Adî el-Cürcânî, el-Kâmil, $7 / 47$.

${ }^{67}$ Ebû Abdirrahmân Abdullāh b. Ahmed b. Muhammed b. Hanbel, el-Câmi'u li Ulûmi İmam Ahmed (Mısır: Dâru'l Fellâhi'l Bühûsi'l İlmiyye, Mısır, 2009), 14/448; Ahmed b. Ali b. Hacer Ebû Fadl İbn Askalânî, Lisânu'l Mîzân (Hindistan: Dâiratü'l Mârifeti'n Nizâmiyye, 1971), 1/160.

68 Ebû Abdillâh Muhammed b. İshâk el-İsfahânî İbn Mende, Fethu'l Bâb fi'l Künye $v e^{\prime} l$ Kâb (Riyad: Mektebetü'l Kevser, 1996), 432. 
arsalarına girdiklerinde evlerinin kapılarını kapatmalarını yasakladı."69

Ata ve Mücâhid'in rivayet ettiği hadisleri, Ezrakî, Abdürrezzak ve İbn Ebî Şeybe birer kez tahriç etmiştir. ${ }^{70} \mathrm{Bu}$ rivayetlerin ortak özellikleri tamamının mürsel olmasıdır. Zira Ata, Hz. Osman zamanında doğarken Mücâhid ise Hz. Ömer döneminin sonlarına doğru h. 21. yılda doğmuştur. ${ }^{71}$

Aynı minvalde başka kanaldan gelen bir rivayete de Ebû'l Ubeyd'in Kitâbü'l Emval'inde rastllyoruz:

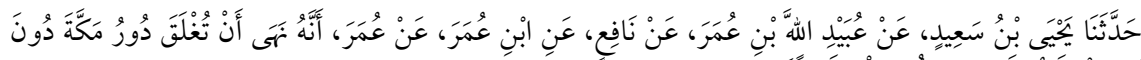

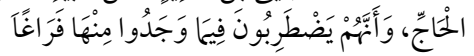

İbn Ömer'den: Ömer (r.a) evlerin kapılarını kapamayı yasakladı çünkü onlar boş yer bulmaya çalışırlar. ${ }^{72}$

İbn Ömer'in başında bulunduğu silsilede bulunan bütün râvilerin sîka kademesinde olduğu ve bu haliyle isnadın sahih olduğu değerlendirilmektedir. ${ }^{73}$

Hadis 9:

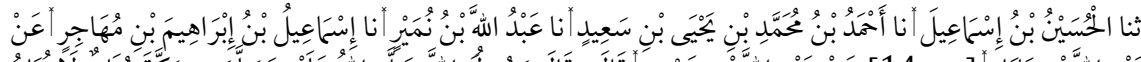

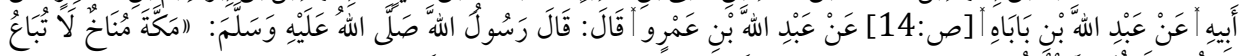

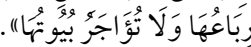

Abdullah b. Amr'dan rivayetle: "Allah Resulü şöyle buyurdu: "Mekke, evleri satılıp kiraya verilmeyen bir bölgedir."74

Yukarıda zikrettiğimiz hadis aynı metinle Hâkim ve Beyhakî tarafından da kaydedilmiştir. ${ }^{75}$ Hâkim ve Dârekutnî'nin eserlerinde Mekke evleri ile ilgili müstakil bir konu açmamasına rağmen Beyhakî, gerek "Sünen" gerekse "Mârife"'de "Mekke Evlerinin Satışı ve Kiralanması" adıyla bâblara yer vermiştir. Bu bâblar içerisinde konuyla ilgili toplam otuz üç rivayet kaydedilmiştir.

Rivayetin ortak râvisi olan İsmâil b. İbrâhim b. Muhâcir, tıpkı babası gibi muhaddislerce ciddî tenkitlere maruz kalmıştır. Buhârî, Ebû Dâvud, Nesâi, Ahmet b. Hanbel, İbn Hibbân, Yahyâ b. Maîn, Kayserânî ve Zehebî gibi isimler onun zafiyeti hakkında ittifak etmişlerdir. ${ }^{76}$

69 İbn Ebî Şeybe, el-Musannef, 3/330 (14685).

70 Ezrakî, Ahbâru Mekke, 2/163-164; Abdürrezzak, el-Musannef, 5/146 (9211); İbn Ebî Şeybe, el-Musannef, 3/330 (14686).

71 Ebû Ömer Dübyan b. Muhammed, el-Muamelâtü'l Maliyye (Riyad: Mektebetü'l Melik Fahd Vataniyye, 2011), 5/144.

72 Ebü'l Ubeyd Kasım b. Sellam el-Bağdadî, Kitâbü'l Emvâl (Beyrut: Dâru'l Fikr, t.y), 85.

73 Ebü'l Ömer Dübyan, el-Muamelâtü'l Maliyye, 5/144.

${ }^{74}$ Dârekutnî, es-Sünen, 4/13 (3018).

75 Ebû Abdillâh Muhammed b. Abdillâh el-Hâkim en-Nîsâbûrî, el-Müstedrek,thk. Mustafa Abdülkadir Ata (Beyrut: Dâru'l Kütübi'l İlmiyye, 1990), 2/61 (2326); Ebû Bekr Ahmed b. el-Hüseyn b. Alî el-Beyhakī, es-Süneni'l Kübrâ li'l Beyhakî, Muhammed Abdülkadir Ata (Beyrut: Dâru'l Kütübi'l İlmiyye, 2003), 6/57 (11183).

${ }^{76}$ Buhârî, Târîhu'l Kebîr, 7/39; İbn Hacer el-Askalânî, Tehzîbü't Tehzib, 1/279; Ebû 


\section{Mekke Evlerinin Satıșı, Kiralanması ve Mirasına İzin Veren Riva- yetler}

Hadis 1:

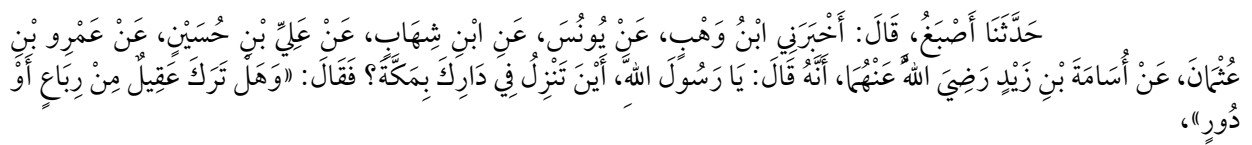

Üsâme bin Zeyd'den, "Üsâme: Yâ Resulullah! Mekke'de nerede konaklayacaksın, kendi evinde mi? diye sormuştur. Resulullah (s.a): "Âkil ev namına bir şey mi bıraktı ki?" buyurdu. ${ }^{77}$

Hadis Tirmizî hariç Kütüb-ü Sitten'nin tamamında yer almıştır. ${ }^{78}$ İlâveten Abdürrezzak, Ahmed b. Hanbel, İbn Hibbân, Dârekutnî, Taberânî ve diğer pek çok hadis kaynağında nakledilmektedir. ${ }^{79}$ Sened ve metin açısından hadisle ilgili herhangi bir cerh ifadesine rastlanılmamıștır.

Buhârî'nin “Mekke'de bulunan evlerin miras bırakılması, alınıp satılmasının hükmü ve tüm beşerin Mescid-i Harâm'da eşit oldukları” bâb başlığı ile yer verdiği bu rivayeti, şahıslara nispet edilmesinden yola çıkarak evlerin alınıp satılması, kiralanması ve miras bırakılmasına ruhsat olarak değerlendirdiğini anlamaktayız. Hadisten çıkarılan ilk anlam "Mü'min, kâfire mirasçı olmaz" iken, Buhârî'nin yorumu ile evlerin Âkil'e nispet edilmesinin maliklere her türlü tasarruf konusunda ruhsat verdiği anlamı çıkarsanmıştır. Mezkûr rivayetten anladığımız diğer bir husus ise, Hz. Peygamber'in Âkil'e olan tepkisi, bu evlerin harem ya da vakıf arazisi olması dolayısıyla satılamama ilkesinin çiğnenmiş olmasından değil; Âkil'in hukuksuzca başkalarına ait olan bir mülke el koymasından kaynaklanmaktadır.

Hadis 2:

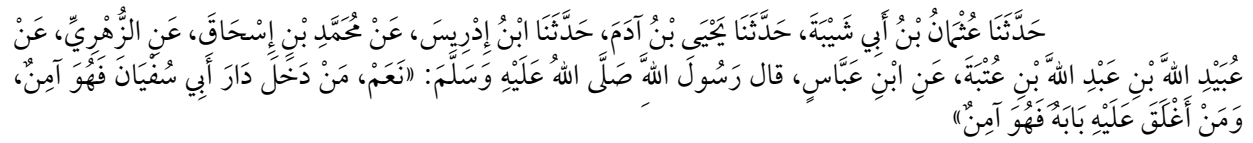

İbn Abbâs'dan rivayetle Hz Peygamber şöyle buyurmuştur: "Ebû Süfyân'ın

Zekeriyyâ Yahyâ b. Maîn b. Avn el-Bağdâdî, Târîh-u İbn Maîn (Şam: Dâru'l Me'mun-i li't Turâs, t.y), 70; İbnü'l Kayserânî, Ma'rifetü't Tezkire, 206; Ebû Abdillâh Şemsüddîn Muhammed b. Ahmed b. Osmân ez-Zehebî, Divânü'd Duefâi'l Metrukîn (Mekke: Mektebetü'n Nahdati'l Hadîse, 1967), 31.

77 Ebû Abdillâh Muhammed b. İsmâil el-Buhârî, el-Câmi 'u's-sahîh, nşr. Muhammed Züheyr b. Nasr (y.y: Dâru Tavki'n-Necât, 2. Basım, 1422/2001), "Hac", 44.

78 Ebü'l-Hüseyn Müslim b. el-Haccâc b. Müslim el-Kuşeyrî, el-Câmi'u's-Sahîh, thk. Fuâd b. Abdilbâkî (Beyrut: Dâru İhyâi't-Türâsi'l-Arabî, 1431/2010), "Hac" 439; Ebû Dâvud, "Ferâiz", 10 (2910); İbn Mâce, "Ferâiz", 6.

79 Abdürrezzak, el-Musannef, 6/14 (9851); Ahmed b. Hanbel, Müsned, 36/84 (21752); Ebû Hâtim Muhammed b. Hibbân b. Ahmed, Sahîhi İbn Hibbân, thk. Şuayb Arnavut (Beyrut: Müessesetü'r-Risale, 1414/1993), 11/552 (5149); Dârekutnî, es-Sünen, 4/21 (3028); Taberânî, el-Mu'cemü'l Kebîr, 1415/1994), 1/167 
hanesinde bulunan güvendedir. Kendi evinde bulunup da üzerine kapısını örten de güvendedir." buyurmuştur. ${ }^{80}$

Ebû Hüreyre, İbn Abbas ve Abdullah b. Rebah'ın rivayette ettiği hadis Müslim, Ebû Dâvud, Abdürrezzak, İbn Ebî Şeybe, Dârekutnî, ve Beyhakî tarafından tahriç edilmiştir. ${ }^{81}$

Hadis, Âkil rivayeti ile birlikte bu bahisteki en sahih iki rivayetten biridir. Rivayet, Kâbe'nin hemen yakınında bulunan bir evin Ebû Süfyân'a nispet edilmesi nedeniyle Mekke evlerinin satışına cevaz verenler tarafından delil olarak kullanılmiştır.

Hadis 3:

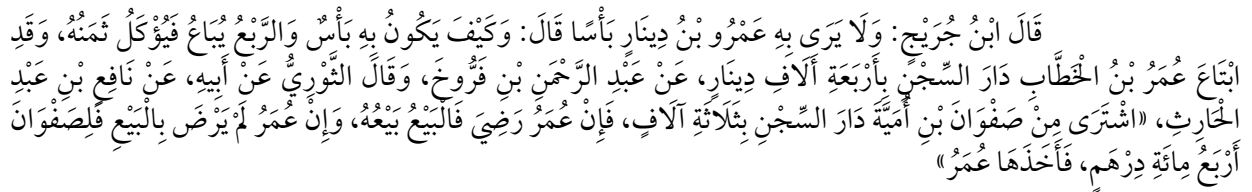

İbn Cüreyc şöyle söylemişti "Amr b. Dinar bunda bir sakınca görmemiştir. Bunda nasıl bir beis olabilir ki ev satılır, parası yenir. Ömer b. Hattab, Dâru's Sicn'i dört bin dinara satın aldı". Nafi' b. Abdülhâris'ten rivayetle: "Savfan b. Ümeyye'den, Dâru's Sicn'i üç bin dinara satın aldı. Eğer Ömer bu satışa rıza gösterirse alışveriş tamam olacak, rıza göstermezse Safvan'a (kapora olarak) dört yüz dirhem kalacaktı. Ömer de bu alışverişi kabul etti."82

Abdürrezzak'ın “Harem'de evlerin kiralanması” konu başlığı ile rivayet ettiği bu hadis, benzer bir senetle Buhârî, Ezrakî, Fâkihî ve Beyhakî tarafından da nakledilmiştir. ${ }^{83}$ Rivayetin diğer vecihlerinde Ömer b. Hattab'ın Mekke'de bir hapishane oluşturmak istediği, bunun için Nafi' b. Abdulhâris'i alışveriş için vekil tayin ettiği ve onun da Süfyân b. Ümeyye'ye ait evi satın aldığı ifade edilmektedir. ${ }^{84}$

Rivayetin ilk bölümünde İbn Cüreyc'in sözünü isnad zikredilmeksizin kaydedilmiştir. Ancak takip eden bölümde rivayetin ikinci kısmını ilgilendiren bir isnad kaydedilmiștir. Abdurrahman b. Ferruh ve Sevrî̀nin babasından zikrettiği bu rivayet, Hz. Ömer'in Mekke emiri Nafi' b. Abdulharis'e dayandırılmaktadır. Buhârî, hadisi isnadsız bir şekilde kaydetmiştir. Kaynaklarda hadise yönelik ciddi bir tenkide rastlanmamıştır.

Hadis 4:

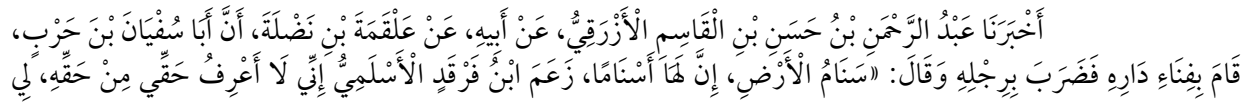

80 Ebû Dâvud, "Harac, İmaret, Fey", 25.

81 Müslim, "Cihâd ve’s Sîre", 84; Ebû Dâvud, "İmâret", 25; Nesâî, "Sûre-i İsrâ" 8; Abdürrezzak, el-Musannef, 5/374 (9739); İbn Ebî Şeybe, el-Musannef, 7/406 (36923); Dârekutnî, es-Sünen, 4/17 (3024).

82 Abdürrezzak, el-Musannef, 5/147 (9213).

83 Buhârî, "Husûmât",7; Ezrakî, Ahbâru Mekke, 2/165; Fâkihî, Ahbâru Mekke, 3/233; Beyhakî, Sagîr, 3/407 (2899).

${ }^{84}$ Beyhakî, Kübrâ, 6/56 (11180). 


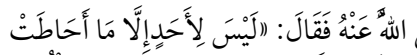

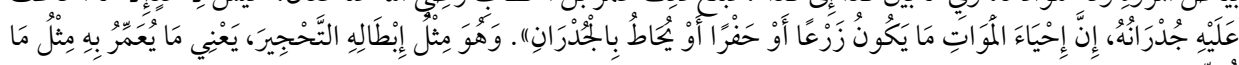

Alkame b. Nadle'den şöyle rivayet olunur: "Ebû Süfyân b. Harb, evinin bahçesinde durdu, ayaklarını yere vurarak şöyle söyledi: "Yerin hörgücü, yerin hörgücü vardır. İbn Ferkad es-Sülemî onun ve benim haklarımızı bilmediğimi iddia ediyor. Oysa Merve'nin beyazı benim, siyahı ise onundur. Şuradan şuraya benimdir." Bu söz Ömer b. Hattab'a ulaşınca Ömer: "Kişi ancak bir arazinin çevresini duvarla çevrelerse onun sahibi olur. Ölü bir araziyi ihya etmek, ekme, kazma ve çevresini duvarla çevreleme ile olur. Bu durum tıpkı bir araziyi imar etmek yerine sadece çakılını ayıklayan kişinin o araziye sahip olamayacağına benzer." 85

İmam-ı Şâfiî̀nin Müsned'inde iki farklı yerde tahriç ettiği bu rivayete Ezrakî, Fâkihî ve Beyhakî de rastlamak mümkündür. ${ }^{86}$ Ezrakî aynı rivayeti, Hz. Ömer'in Ebû Süfyân’a yönelik "O eski bir zalimdir.” ilavesiyle zikrederken, Beyhakî, yukarıda

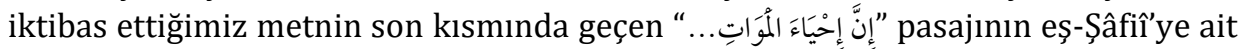
olduğu yönünde zannını ifade etmiştir. Kaynaklarda hadisin sıhhati ile ilgili bir değerlendirmeye rastlanılmamıştır.

Rivayette hem Ebû Süfyân'ın hem de Hz. Ömer'in sözlerinden harem bölgesinde bulunan arsalar üzerinde şahısların mülkiyet hakkı olabileceği anlaşılmakla birlikte bu durum Mekke arazilerinin de benzer şekilde alınıp satılabileceği şeklinde yorumlanmiştır.

\section{Mezhep İmamlarının Hadislere Dair Yorumları}

\subsection{Hanefîlerin Yorumları}

Yapılan incelemede Hanefî̀ ilim adamlarının Mekke evlerinin satıșı ve kiralanması konusunda çok farklı görüşe sahip oldukları gözlemlenmiştir. Bu ihtilafın sebebi kimilerince Mekke'nin fethediliş yönteminin farklı yorumlanmasından kaynaklanmaktadır. Zira Mekke, eğer kılıç yolu ile fethedildi ise harem içerisinde bulunan hiçbir taşınmazın satışı caiz görülmemiştir. Çünkü fetih öncesi özel mülkiyet olan söz konusu ev ve araziler, fetih sonrası vakıf metasına dönüșmüş olacaktır. Bu durumun aksine şayet Mekke barış yoluyla fethedildi ise bu takdirde bütün taşınmazların satışı, kiralanması ve mirası caiz olacaktır. Çünkü özel mülkiyet vasfına dokunulmamıştır. ${ }^{87}$

Hanefîlerce serdedilen ilk görüş, Mekke evlerinin satışı ve kiralanmasının mutlak olarak haram olduğu yönündedir. Meseleyi tahrim bağlamında ele alan bu

85 Şâfiî, el-Müsned, 1/382; 2/134.

86 Ezrakî, Ahbâru Mekke, 2/164; Fâkihî, Ahbâru Mekke, 3/252; Beyhakî, Ma'rifetü's

Sünen-i ve'l Âsar, 9/19 (12214), (12215), (12216).

${ }^{87}$ Ebû Muhammed Mahmud b. Ahmed Bedreddin el-Aynî, el-Binâye fî Şerhi'l Hidâye (Beyrut: Dâru'l Kütübü'l İlmiyye, 2000), 12/227. 
yaklaşım, aşağıda zikredeceğimiz üç rivayetle temellendirilmeye çalışılmıştır: ${ }^{88}$

1. Ubeydullah b. Yezid'den rivayetle Allah Resulü şöyle buyurmuştur: "Allah, Mekke'yi haram kılmıştır. Onun evlerini satmak ve ürününü yemek haramdır."89

2. Abdullah b. Amr'dan rivayetle: "Allah Resulü şöyle buyurdu: "Mekke, evleri satılıp kiraya verilmeyen bir bölgedir."90

3. Alkame bin Nadle'den şu şekilde nakledilmiştir: "Hz. Peygamber, Hz. Ebû Bekir ve Hz. Ömer dönemlerinde Mekke evleri hep sevâib (yâni oturanların mülkü olmayıp ihtiyaç sahiplerine terkedilen yer) olarak nitelendirildi. İhtiyacı olan oturur ihtiyacı olmayan da onu ihtiyacı olana bırakırdı."91

İmam-ı Âzam'a dayandırılan ilk görüşe göre yukarıda zikrettiğimiz rivayetler ile Mekke evlerinin satışı ve kiralanmasının haram olduğuna bir işaret olduğu söylense de söz konusu evlerin tasarrufları hakkında mutlak haram olduğu yaklaşımının Hanefî kaynaklarda oldukça sınırlı kaldığı ve sonraki dönem fıkıhçılar tarafindan benimsenmediği söylenebilir.

Hanefîlerin ikinci görüşünde ise Mekke evleri ve bu evlerin üzerinde bulunduğu arazilerin birbirinden hükmen farklı oldukları dile getirilmiştir. ${ }^{92} \mathrm{Bu}$ durum Ebû Yûsuf (ö. 182/798) tarafından şöyle ifade edilmiştir: "Mekke evlerinin satışı ve kiralanmasında herhangi bir beis yoktur. Ne var ki Mekke evlerinin üzerinde bulunduğu araziler böyle değildir. Onların satışı mekruhtur."93

Hanefîler, Mekke evlerinin bulunduğu araziyi harem sınırları içerisinde görmekle beraber, bu arazilerin Mescid-i Harâm ile eşit şartlara ve yaptırımlara sahip olduğunu savunmuşlardır. Buna göre Haremde avlanmak ya da ihramsız olarak hac ve umre yapmak nasıl haramsa, Mekke evlerinin üzerinde bulunduğu arazinin satıșı da öylece haramdır. Çünkü o arazi Safâ ve Merve hatta Kâbe mesabesindedir. Zira Hz. İbrâhim, Mekke arazilerinin tamamını vakfetmiştir. Bunun yanı sıra arazilerin üzerine yapılan ev ve dükkânların çeşitli tasarrufları ise caizdir. Çünkü bu ev ve dükkânlar, oraya kendilerini inşa ederek emek harcayanların öz mülküdür. Şayet bu evleri Mekke arazisinden alınmış toprak ile yapmış olsa bile hüküm değişmez. ${ }^{94}$

Ebû Hanîfe'den aktarılan başka bir görüşe göre ise Mekke evlerinin satışının caiz olduğu ve hatta bu evlerin Şuf'a hakkının bile bulunduğu rivayet edilmektedir. Bununla birlikte rivayetin devaminda onun normal zaman ile hac zamanının arası-

${ }^{88}$ Ahmed b. Muhammed el-Kudûrî, et-Tecrîd-ü li'l Kudûrî (Kahire: Dâru's Selam, 2006), 2633.

89 Dârekutnî, es-Sünen, 4/12 (3015).

90 Dârekutnî, es-Sünen 4/12 (3018).

91 İbn Mâce, "Menâsik", 102.

92 Muhammed Emîn b. Ömer b. Abdilazîz ed-Dımaşkī, Reddü'l Muhtar alâ Durri'l Muhtâr (Beyrut: Dâru'l Fikr, 1992), 6/392.

93 Abdullah b. Muhammed el-Mavsilî, el-İhtiyâr-u li Ta'lîli'l Muhtâr (Kahire: Matbaâtü'l Halebî, 1937), 4/162.

${ }_{94}$ Mevsilî, el-İhtiyâr, 4/162. 
nı ayırdığı da nakledilmektedir. Buna göre normal zamanlarda evlerin tasarrufları konusunda maliklere yetki verilirken hac zamanı geldiğinde bu yetki ilga edilerek Mekke evlerinin kiraya verilmesi kerih görülmüştür.95 Aynı doğrultuda Ebû Hanîfe'den gelen başka bir rivayette ise hacllara şöyle seslenilmiștir: "Eğer misafir edecek yerleri var ise gidin! Mekkeliler sizleri misafir etsin; ancak yerleri yok ise misafir olmayınız!" Ebû Hanîfe'nin bu sözlerini te'vil eden Hişâm, onun misafir hacıları Mekkelilere yönlendirmesine neden olan gerekçenin Hac sûresinin yirmi beşinci âyetinde geçen "Yerli ve yabancılar orada eșittir." ifadesi olduğunu söylemiştir. Ayrıca Hişâm, Ebû Hanîfe'nin hac zamanı ile sair zamanların arasını ayırmasına işaret ederek şöyle bir izahta bulunmaktadır: "Hac aylarında insanlar kalabalıklaşıyor. Bu durum onların barınma ihtiyaçlarını karşılamada birtakım zaruretler doğuruyor. İște bu noktada Ebû Hanîfe, hacllara bir merhamet ve fazilet göstergesi olarak sanki kendi mülklerinde kalıyorlarmış gibi Mekkelilerin evlerinde kalmalarını sağlıyor. Hac zamanı bittiğinde ise zarûret ortadan kalktığı için Mekkelilerin evlerini paylaşmaları gerekmiyor."96 Buna mukabil İmameyn olarak bilinen Ebû Yûsuf (ö. 183/799) ve İmam-ı Muhammed (ö. 189/804) Mekke evlerine dair hocaları Ebû Hanîfe'nin gördüğü bu sınırlı keraheti dahi görmediklerini ifade etmişlerdir. ${ }^{97} \mathrm{Bu}$ hususta وَهَلْ تَرَكَ عَقِيَلْ مِنْ رِبَّاع (Âkil bize ev mi bıraktı) rivayeti évler ve arazilerin Âkil'e nispet edilmesinden ötürü maliklerin her türlü tasarruf konusunda muhayyer olduklarına yormuşlardır. ${ }^{99}$ İmameyn'in bu hususta en güçlü delil olarak gördükleri Âkil hadisinin bütün hadis otoritelerinin teveccühüne rağmen İmam-ı Âzam tarafından zikredilmemesi dikkate şâyandır.

Ebû Hanîfe'ye dayandırılan bir başka görüş ise Mekke'nin hicret diyarı olmamasından ötürü oraya dışardan göç edip yerleşmenin kerih olduğu fetvasıdır. Bu hususta, Ebû Hanîfe'nin Peygamber'ın (a.s) Mekke'den hicret etmesinden dolayı orada yaşamayı ve Harem-i Şerîf'e komşu olmayı kerih gördügü nakledilmiştir. Bu itibarla Hanefî fakihlerce harem bölgesine dışardan gelen yabancıların yerleşmesi hoş karşılanmamış ve şehir içinde yeni bir binanın inşa edilmesine cevaz verilmemiştir. Bu yaklaşımda "منى مناخ من سبق" (Mina önce gelene aittir) ${ }^{100}$ rivayetinin de etkili olduğu ileri sürülmektedir. Burhaneddin el-Buhârî (ö. 616/1219), bu rivayeti konuyla şöyle ilintilendirmektedir: "Mina, bütün insanlığın istifadesine sunulmuş ortak bir mekândır. Mina, ismi gibidir. Orası hacıların hayvanları boğazladı̆̆ı yerdir. Mina'da yapılan yapılar oranın özel bir bölge olduğu algısını eksiltir."101

95 Mevsilî, el-İhtiyâr, 4/162.

96 Burhânüddîn (Burhânü'ş-Șerîa) Mahmûd b. Ahmed b. Abdilazîz el-Mergīnânî, elMuhîtü'l Burhânî (Beyrut: Dâru'l Kütübi'l İlmiyye, 2004), 2/459.

${ }^{97}$ Ali b. Ebî Bekir Ebû'l Hasan Burhâneddin, el-Hidâyet-ü fi Şerhi'l Bidâye (Beyrut: Dâru'l İhyâ-i Türâsi'l Arabî, t.y), 4/379.

98 Buhârî, "Hac", 44.

${ }^{99}$ Zeynuddin b. İbrâhim b. Nüceym, el-Bahru'r Râik (y.y: Dâru'l Kütübi'l İslâmî, t.y), 8/231.

100 Ebû Dâvud, "Menasik", 2019.

101 Burhaneddin el-Buhârî, el-Muhîtü'l Burhânî, 2/459. 
Ebû Hanîfe'den son olarak naklettiğimiz bu görüşün dini gerekçeler dışında sosyolojik birtakım saikler etrafında temellendirildiği de iddia edilebilir. Örneğin Mekke'nin coğrafi şartlarının uygun olmaması nedeniyle daha kalabalık bir nüfusun iskân, hayvancılık ve alt yapı gibi alanlarda baş edilemez sorunlar doğurabileceği öngörüsü bu kerahetin gerekçeleri arasında zikredilebilir. Nitekim beldenin bütün Müslümanlar için kutsal bir mekân olması nedeniyle yoğun bir talep ile karşılaşması beklenmedik bir durum olmayacaktır. Bu noktada Ebû Hanîfe'nin ileri bir şehircilik mentalitesine sahip olduğu ileri sürülebilir.

\section{2. Şâfiîlerin Yorumları}

Şafiîler, bu konudaki mevcut tartışmaları, Mekke'nin fethedilme șeklinin yanlış yorumlanmasına bağlamaktadırlar. Zira onlar, Mekke'nin sulh yoluyla fethedildiği ve bu itibarla şehirde bulunan ev, arazi, bahçe ve meraların ganimet ve vakıf malına dönüştürülmesinin mümkün olmadığını savunmuşlardır. Bu hususta "Eğer inkârcılar sizlerle savaşacak olsalardı arkalarına dönüp kaçarlardı"102, "Bu mallar bilhassa, Allah'tan bir ikram ve rıza ararken ve Allah'ın dini ve peygamberine yardım ederken topraklarından ve mallarından mahrum edilen fakir muhacirlerindir" 103 âyetleri ile istidlal eden Şafiîler, Mekke'nin fethi esnasında herhangi bir çarpışmanın olmadığı ve dolayısıyla Mekke'nin sulh yoluyla alındığını ispatlamaya çalıșırlar. ${ }^{104} \mathrm{Bu}$ sebeple Harem'de bulunan taşınmazlarla ilgili özel bir hukukun doğmayıp daha önceki maliklerin hak sahibi olduklarını ileri sürmektedirler. ${ }^{105}$

Şafiî âlimler bu gibi akıl yürütme örnekleri bir tarafa rivayet malzemelerinden de en iyi şekilde yararlanmayı bilmişlerdir. Buna göre Mekke evlerinin vakıf arazisi mi yoksa özel mülkiyet mi olduğu konusunda "müttefekun aleyh" olarak nitelendirilen "Âkil bize ev mi bıraktı?"106 hadisini en güçlü delil olarak görmektedirler. ${ }^{107}$ Aynı doğrultuda fetih günü Hz. Peygamber tarafından ilan edilen "Ebû Süfyân'ın evine giren güvendedir, silahını atan güvendedir, kapısını kapatan güvendedir"108 manifestosu ve Nafi' b. Abdülhâris'ten rivayet edilen "Savfan b. Ümeyye'den, Dâru's Sicn'i üç bin dinara satın aldı. Ĕger Ömer bu satışa rıza gösterirse alışveriş tamam olacak, rıza göstermezse ise Safvan'a (kapora olarak) dört yüz dirhem kalacaktı."109 rivayetini Mekke evlerinin de diğer evlerden farksız olarak özel mülkiyet kapsamında değerlendirilmesi konusunda delil olarak kullanmışlardır. ${ }^{110}$ Buna paralel olarak Mâverdî (ö. 450/1058), sahâbeden Abdullah b. Cahş'ın

102 el-Fetih 48/22.

103 el-Haşr 59/8.

104 Kemaleddin Muhammed b. Musa ed-Demirî, en-Necmü'l Vehhac fi Şerhi'l Minhâc,

(Cidde: Dâru'l Minhac, 2004), 11/365

105 Nevevî, el-Mecmu', 9/248.

106 Buhârî, "Hac", 44.

107 Nevevî, el-Mecmû', 9/249.

108 Müslim, "Cihad ve’s Siret", 86.

109 Buhârî, "Husûmât", 12; Abdürrezzak, el-Musannef, 5/147 (9213).

110 Ebü'l-Hasen Alî b. Muhammed el-Mâverdî, el-Hâvi'l Kebîr (Beyrut: Dâru'l 
Ebû Süfyân'ı hicret esnasında kendi evini sattığı gerekçesi ile Nebi (a.s)'a şikayet ettiğini ve Hz. Peygamber'in "Cennette ondan daha hayırlı bir ev istemez misin?" diyerek akdi onayladığını rivayet etmiştir. ${ }^{111}$

Şafîiler, Mekke evlerinin satışı ve kiralanması ile ilgili yasağı savunan cenahın en önemli dayanağı olan "Yerli ve misafirler için eșit kıldığımız Mescid-i Harâm"112 âyetinden yola çıkarak Harem içerisinde herkesin aynı haklara sahip olduğu düşüncesine şiddetle karşı çıkmışlardır. Zira âyetin bahsettiği yerli ve yabancı kimselerin eşit oldukları yer yalnızca Mescid-i Harâm'la sınırlı görülmüștür. Aksi durumda ise mescid mesabesinde olacağı için bütün Mekke'de yitik aramak, hayvan boğazlamak ve develerin gübrelerini sağa sola saçmak gibi normalde caiz olan şeylerin de haram olması gerektiği söylenmiștir. ${ }^{113}$

Karşıt tarafın delil olarak kullandığı rivayet malzemesi de Şafîiler tarafından hedef alınmıștır. Bu rivayetlere yöneltilen ortak eleştiriler hadislerin isnadındaki zayıf râviler etrafında yoğunlaşmıştır. Özellikle yasaklama ifade eden hadislerin isnad edildiği İbrâhim b. Muhâcir, ağır șekilde tenkit edilerek ondan gelen hiçbir haberin dikkate alınmaması gerektiği vurgulanmıştır. ${ }^{114}$ Bunun yanı sıra bazı hadislerin bağlamından kopartılarak yanlıș yorumlandığı da görülmektedir. Örneğin "Ey Allah'ın Resulü Mina'da senin için güneșten gölgelenebileceğin bir göz oda yahut bir bina yapsak ya!" sorusuna 0, "Hayır, Orası önce gelene aittir." buyurdu. ${ }^{115}$ rivayeti, Hanefîlerin iddia ettiği gibi Mina bölgesinin tasarrufuna ilişkin bir yasaklamaya değil günlük hayatta kullanıma uygun olmayan ölü araziler olduğuna hamledilmiştir. ${ }^{116}$

Şafiî fukehâsı tarafından eleștirilen bir bașka rivayet ise "Mekke evlerine ancak sevâib (yâni oturanların mülkü olmayıp ihtiyaç sahihlerine terkedilmiş olarak) denile geldiği halde Hz. Peygamber, Hz. Ebû Bekir ve Hz. Ömer vefat ettiler. Kim (meskene) muhtaç ise (Mekke evlerinde) oturur ve kim muhtaç değil ise ihtiyâcı olana (bedelsiz olarak) bırakır."117 hadisidir. Şafiî muhaddis Beyhakî, rivayeti isnad açısından ele alarak Alkame b. Nadle'nin ${ }^{118}$ kimileri tarafından zannedildiği gibi ashabdan değil tabiin nesline ait olduğu tespitinde bulunmuştur. Bu durum aynı zamanda hadiste bir ınkıta bulunduğu anlamına gelmektedir. Buna rağmen ilim ifade edebileceği düşüncesini benimseyen Beyhakî, hadisi muhaliflerin iddia ettiğinden biraz farklı anlamıştır. Ona göre, rivayet, iddia edildiği gibi bir yasaklama getirmeyip, yalnızca cömert Mekke insanının asr-ı saadette fakir ve ihtiyaç sahibi

Kütübi'l İlmiyye, 1999/1419), 5/386.

111 Mâverdî, el-Hâvi'l Kebîr, 5/386.

112 Hac $22 / 25$

113 Nevevî, el-Mecmû', 9/250.

114 Nevevî, el-Mecmû', 9/251; İsmâil b. İbrâhim b. Muhâcir hakkında. bk. Buhârî, Târîhu'l Kebîr, 6/39; İbn Hacer el-Askalânî, Tehzîbü't Tehzîb, 1/279.

115 Ebû Dâvud, "Menasik", 90.

116 Nevevî, el-Mecmû', 9/251.

117 İbn Mâce, "Menasik", 102.

${ }^{118}$ Alkame b. Nadle hakkında ayrın bilgi için 1. hadis açıklamalarına bakınız. 
Müslümanları gözeterek uygulayageldikleri güzel bir âdeti haber vermektedir.119

Özetle Şafîilerin bu konu hakkındaki düşünceleri Mekke evleri ile Mescid-i Harâm'ın farklı hukuka sahip olduğu fikrine dayanmaktadır. Bundan dolayı Hac suresi 25. âyette ifade edilen eşit olma keyfiyetinin yalnızca Mescid-i Harâm'a ilişkin özel bir durum olduğu savunulmuştur. Bu kapsamda harem-i şerife ilişkin sahih hadislerde belirtilen mahsus yasakların bütün Mekke'yi kuşatacak şekilde genişletilmemesi gerektiği savunulmuştur. ${ }^{120}$ Dolayısıyla Şafiîlere göre Mekke evlerinin satışı, kiralanması, miras bırakılmasının yanı sıra hibe edilebilmesi de mümkündür. ${ }^{121}$

\subsection{Mâlikîlerin Yorumları}

Mâlikî kaynaklarda Mekke evlerinin satıșı ve kiralanması konusunda yüzeysel bilgilerin yer aldığı görülmektedir. Mâlikîler, bu meselede tıpkı Şafiîler gibi, Mekke'nin ele geçiriliş yöntemi üzerinde durulması gerektiğini ifade etmişlerdir. Onlara göre Mekke, Şafîilerin aksine kılıç yoluyla "عنوة" (Zorla) fethedilmiştir. İmam-ı Mâlik (ö. 179/795) bu görüşünü, Müslümanların Mekke’ye silahlarını göstererek girmelerine bağlamıştır. Çünkü silahların gösterilmesi ve eman dileyene eman vermek, ancak savaş ortamının geçerli olduğunun göstergesidir. ${ }^{122} \mathrm{Bu}$ anlayış sonraki dönem Mâlikî âlimlerin de kabulüdür. Ancak fetih gerçekleştikten sonra, oradaki evlerin kimlere bırakıldığı hususunda birtakım ihtilaflar ortaya çıkmıştır. Bu hususta iki farklı görüş ortaya çıkmıştır. Bu görüşlerin ilkinde Hz. Peygamber'in Mekke'ye olan hürmetinden dolayı evleri eski sakinlerine bırakıp ganimet olarak taksim etmediği ifade edilmiştir. Bunun aksine Mezhebin ana görüşü olan diğer yaklaşımda ise Mekke evlerinin ganimet olarak pay edildiği savunulmaktadır. ${ }^{123}$ Öte yandan Mâlikîler de "Yerli ve misafirler için eşit kıldığımız Mescid-i Harâm"124 âyetini tıpkı Hanefîler gibi anlayarak Mekke üzerinde yerliler ve dışardan gelenlerin aynı haklara sahip olduğunu benimsemişlerdir. ${ }^{125}$

Bazı Mâlikîler ise evlerin satıșı ve kiralanmasına cevaz vermişlerdir. Aralarında İbn Kasım (ö. 191/806) gibi isimlerin de bulunduğu bu gruba göre açılan kuyu nasıl onu açanınsa evler de onu yapana aittir. Bu uygulama asırlar boyunca böyle devam etmiş olup bunun aksini gerektirecek bir karine mevcut değildir. ${ }^{126}$ Bağdatlı bazı Mâlikîler ise, verilen bu cevazı takyit edip, satışa konu olabilecek mal-

119 Nevevî, el-Mecmû', 9/251.

120 Mâverdî, el-Hâvi'l Kebîr, 5/386.

121 Mâverdî, el-Hâvi'l Kebîr, 7/552.

122 Ebû Abbas Ahmed b. İdris El-Karâfî, ez-Zehîra (Beyrut: Dâru'l Garbi'l İslâmî, 1994), 5/406.

123 Ali b. Muhammed El-Lehmî, et-Tebsira (Katar: Vüzerâtü'l Evkâf-i ve'ş Şuûni'l İslâmî, 2011), 11/5085.

124 el-Hac 22/25.

125 Ebû Velid Ahmed b. Rüşd, el-Beyan ve't Tahsîl (Beyrut: Dâru'l Garbi'l İslâmî, 1988), 3/405.

126 Lehmî, et-Tebsira, 11/5085. 
ları, evler ve üzerlerine inşa edilen çatılarla sınırlı tutmuş ancak arazilerin satışına sıcak bakmamışlardır. Ayrıca evlerin bulunduğu arsaların başka bölgelerde olduğu gibi sahibinin izni olmadan girilememesi kuralının ise burada geçerli olmadığını iddia etmişlerdir. ${ }^{127}$

\subsection{Hanbelîlerin Yorumları}

Mekke evlerinin satışı ve kiralanması konusunda mezheplerin genel olarak kendi içinde bir tutarlılı̆̆ olmasına karşın Ahmed b. Hanbel'in birbirinden farklı çok sayıda görüșe sahip olduğu aktarılmıștır. Bu rivayetlerden ilkinde, "Mekke evleri kimsenin değildir, ihtiyacınız varsa girin, oturun." denmesi karşısında Ahmed b. Hanbel'in: "Mademki o evler kimsenin değil, o halde Peygamber (a.s), fetih günü o evleri niçin sahiplerine izâfe etti yahut Ömer, Dâru's Sicn'i Safvan'dan nasıl satın aldı, ya da madem ev kimsenin değil o halde vatandaş, içine haremiyle girip nasıl oturuyor?” sözleriyle tepki gösterdiği nakledilmiștir. "Girin, Mekke evlerinde sahipleriyle beraber oturun" diye söyleyen birine, "Nasıl girip oturuyorsun, eğer o evin sahibi nazarında bir itibarın varsa girer oturursun. Tabi bir de adamın evinin müsait olması gereklidir. Şayet Safvan b. Ümeyye'nin evi gibi geniş sofalı bir evi varsa, odalardan birine girer oturursun, ancak tek göz odalı bir evin içinde eşi ve çocuklarının yanında seni kimse misafir etmek zorunda değildir" dediği aktarılmiştır. ${ }^{128}$

Bu bağlamda İbn Kudâme (ö. 682/1283), "Kapısını kapatan güvendedir" hadisine işaret ederek fetih günü şahıslara ait malların zayi edilmediği ve bunun aksini söyleyen rivayetlerin tamamının zayıf olduğunu söylemiştir. Ayrıca raşid halifelerden bu zamana kadar evlerin satışına dair bir teamül bulunduğu ve kimsenin buna karşı çıkmadığına da değinmiştir. Ona göre Hz. Peygamber, nasıl ki Hevazin'i sahiplerine bağıșladı ise öylece Mekke'yi de sahiplerine bağıșlamıștır. ${ }^{129} \mathrm{Bu}$ yaklaşım içerisinde olan Hanbelîler, Ahmed b. Hanbel'in şahitliği ile gerçekleșen Şafiî ve İshâk (ö. 238/852) arasındaki münazarada Şafiî̀nin delillerini daha baskın bulmaktadırlar. ${ }^{130}$

İmam Ahmed'e isnad edilen ikinci görüș ise bu evlerin tasarruflarının caiz olmadığı yönündedir. Ona göre Mekke zorla fethedilmiştir. Şu rivayette Mekke'nin kahr yoluyla fethedilmesinin delili olarak kabul edilmiștir: "Allah, Mekke'yi fillerden kurtardığı gibi Resulünü ve mü'minleri de Mekke ahalisine hâkim kılmıştır."131 Öte yandan Hz. Peygamber'in fetih günü içlerinde İbn Hatal ve Mikyas b.

127 Ebû Abdullah Muhammed b. Ali et-Temimî, Şerhu't Telkîn (y.y: Dâru'l Garbi'l İslâmî, 2008), 2/968.

128 Ebû Abdillâh Ahmed b. Muhammed b. Hanbel, el-Câmiu'l Ulûmi'l İmam Ahmed el-Fıkh (Mısır: Dâru'l Fellâh-i li'l Bühûsi'l İlmiyye, 2009), 9/68.

129 Șemseddin Ebû'l Ferec İbn Kudâme, Șerhu'l Kebîr (Mısır: Hicr-u li't Tebâati ve'n Neșr ve't Tevzi' ve'l i'lan, 1995), 11/75.

130 Takiyuddin Ebû'l Abbas İbn Teymiyye, Mecmuû Fetâvâ (Medine: el-Mecma' Melik Fahd li't Tebâati Mushafi'ş Şerif, 1995), 34/113.

131 Müslim, "Hac", 447. 
Subâbe'nin de bulunduğu dört kişi hakkında öldürme emri vermiş olması da Mekke'ye girişin kılıç yoluyla olduğu şeklinde yorumlanmıştır. ${ }^{132}$ Hanbelî bilginlerden Merdâvî (ö. 885/1480), "el-İnsaf" isimli eserinde "Mekke evlerinin satışı caiz değildir" fetvasının ve "Mekke zorla fethedilmiştir" görüşünün her ne kadar ihtilafa uğrasa da mezhebin esas görüşü olduğunu belirtmiştir. ${ }^{133}$

Ahmed b. Hanbel (ö. 241/855)'den gelen üçüncü ve son görüş ise oğlu Abdullah (ö. 290/902) tarafından aktarılmıştır. Rivayette Abdullah, bir seferinde babasına Mekke evlerinin hükmünü sorduğunu ve babasının şu cevabı verdiğini söyler: “Her ne kadar başkaları Hz. Ömer'in Dâru's Sicn'i satın almasını delil göstererek ona ruhsat verseler de bize göre Ömer, bu işi ümmetin menfaati doğrultusunda yapmıştır, dolayısıyla kamu yararı gözetilen bir durumdan kişisel bir izin çıkmaz. Bunun için bize göre Mekke evlerinin tasarrufu mekruhtur." ${ }^{34}$ Aynı eserde Abdullah, babasının, İmam Şafiî ve İshâk b. Raheveyh arasında cerayen eden bir münazaraya tanık olduğuna değinmiştir. Abdullah, babası Ahmed b. Hanbel'in, bu münazarada daha önce zikrettiğimizin aksine Mekke evlerinin tasarruflarının kerahatini savunan İshâk'ı daha baskın bulduğuna atıfta bulunmuş ve bu konuda gelen rivayetlerin çoğunun kerahate işaret etmesinden ötürü evlerin alım ve satımından uzak kalmanın kendisine daha sevimli geldiğini aktarmıştır. ${ }^{135}$

Hanbelîlerin farklı olarak değindiği bir diğer konu ise Mekke dışında inşa edilen ve Harem bölgesine çekilerek getirilen evin durumu ile ilgilidir. Mezhebe göre taşınarak getirilen bu evin hükmü çadır ve benzeri geçici evlerin hükümleri ile aynıdır. Bu geçici ev harem diyarının taşından ve toprağından yapılsa bile durum değişmez. ${ }^{136}$

\section{Sonuç}

Yapılan bu incelemeler sonucunda Mekke evlerinin satışı ve kiralanması ile ilgili yasak koyan ve izin veren iki tür rivayet grubunun bulunduğu görülmektedir. Özellikle hadis âlimlerince kısmî bir teveccüh gören rivayetler bulunmakla beraber bu rivayetlerin çoğunlukla zayıf olarak değerlendirildiği anlaşılmaktadır. Mekke evlerinin satılması ve kiralanmasına izin verdiği çıkarımı yapılan rivayetlerin ise bir kısmının Buhârî, Müslim ve Ebû Dâvud gibi muteber isimler tarafından sahih olarak rivayet edildiği görülmüştür. Bununla beraber İbn Ebî Şeybe, Dârekutnî, Tahâvî ve Beyhakî gibi pek çok hadis müellifin her iki türden rivayetleri hiçbir hüküm belirtmeksizin kaydettiğini, diğer taraftan fikhî görüşlerini ortaya koymakla tanınan Buhârî, Müslim gibi otoritelerin bu hususta fikirlerini açıkça ortaya koymadıkları gözlemlenmiştir. Genel olarak evlerin satışının yasaklayan rivayetlerin

132 İbn Kudâme, Şerhu'l Kebîr, 11/74.

133 Ebû Yakub Mervezî el-Kevsec, Mesâilü'l İmam Ahmed ve İshâk b. Raheveyh (Medine: Îmâdetü'l Bahsi'l İlmiyye, 2002), 5/2305.

134 Ebû Abdillâh Ahmed b. Muhammed b. Hanbel, Mesâilü'l Ahmed b. Hanbel

Rivayet-ü ibnühü Abdullah (Beyrut: el-Mektebü'l İslâmî, 1981), 234.

135 Ahmed b. Hanbel, Mesâil, 234.

136 İbn Kudâme, Șerhu'l Kebîr, 11/76. 
hadis müktesebatı açısından zayıf olarak değerlendirilmesine karşın, aksi görüş bildiren Şâfiîlerin kullandıkları rivayetlerin sahih hadislerden müteșekkil olduğu tespit edilmiştir. Ancak zayıf olarak nitelendirilen rivayetlerin diğer üç mezhep tarafından dikkate alındığı ve genel olarak bu evlerin satışı ya da kiralanması ile ilgili tasarrufların caiz bulunmadığı görülmüştür. Bize göre, hadislerin zayıf olmalarına rağmen fıkıhçılar tarafından kabul görmesi onların maslahatçı yaklaşımlarından kaynaklanmaktadır. Bu maslahat, bölgenin ticârî bir rekabet alanına dönüşmesini engelleyerek Müslümanların hac ibadetlerini dolaylı da olsa kısıtlayıcı bir durum olmaksızın kolaylıkla yapmalarını sağlamaya yöneliktir. Diğer bir söylemle bu rivayetlerin, özellikle Mekke'nin ele geçiriliş yöntemi etrafında dönen tartışmalar neticesinde edinilen kanaatlere destek bağlamında bir dolgu malzemesi olarak kullanıldığını da söyleyebiliriz. Konu ile ilgili "Âkil hadisi" gibi sahih rivayetlerlere ise Ebû Hanîfe ve İmam Malik gibi otoriteler tarafından atıfta bulunulmaması oldukça dikkate şayandır. Öyle zannediyoruz ki bu durumu tedvin döneminden önce yaşadıkları için kendilerine bahsi geçen rivayetlerin ulaşmamıș olabileceği ihtimali ile açıklanabilir. Bunun yanı sıra Hanefî, Mâlikî ve Hanbelî mezheplerinde ana görüşün hilafına bazı beyanlarda bulunulduğunu ancak Şâfiî mezhebinde ise tam bir birliktelik içinde olduğunu gözlemledik. Mezhep içerisinde aradan uzun yıllar geçse de genel kanaatin dıșına çıkılmamıştır. Bir hadisçi refleksi ile hareket eden İmam Şâfiî, söz konusu evlerin satışı ve kiralanmasını yasaklayan rivayetlerin zayıflığına dikkat çekerek hadis usûlü verileri doğrultusunda daha sahih olan rivayetler ışığında görüşünü şekillendirmiştir. Sonuç olarak Şâfiî̀nin görüşünün hayatın doğal akışına ve iktisâdî-ticarî yaşamın dokusuna daha uygun olduğunu söyleyebiliriz. Bununla beraber günümüz Hicaz topraklarını elinde bulunduran Suud yönetiminin, Hac farizasını yerine getirmek için gelen mü'minleri ekonomik olarak zorlayan tutumları nedeniyle, Mekke evleri üzerinden para kazanmayı sakıncalı gören mezhep imamlarımızın bu gibi problemleri öngörerek ideal olana işaret etmek için sarf ettikleri çabalar da nazarımızda oldukça değer kazanmaktadır. Öte yandan Hanbelî mezhebinin katı bir uygulayıcısı olan Suud yönetiminin bu hususta mezhebin genel tavrını terk etmesi veya en azından mezhebin hassasiyetini görmezden gelmesi dikkatlerden kaçmamalıdır.

Sonuç olarak konuyla ilgili bütün müktesebât incelendiğinde Mekke evlerinin satışı ve kiralanmasının câiz olduğu söylenebilir. "Mekke evleri satılmaz, kiralanmaz." gibi rivayetlerin ise hac ibadetini yerine getirmek için Mekke'ye gelen hacılara iyilik ve ikram bağlamında bir teşvik olarak değerlendirilmelidir. Ancak bütün Müslümanlar için kutsal olan harem bölgesinin inanç turizmi söylemleri ile bir sömürü aracı olarak görülmemesinin de önüne geçilmelidir. Bu ülkünün ise bölgenin kutsiyetini bütün dünyevi kazançların üstünde tutan güçlü bir İslâm birliği eliyle gerçekleştirilebileceğine inanmaktayız.

\section{Kaynakça}

Abdürrezzak, Ebû Bekr Abdürrezzâk b. Hemmâm b. Nâfi‘ es-San'ânî. el-Musannef. thk. Habîbu'r Rahman el- Azmî. Hindistan: Meclisü'l İlmî, 4103.

Ahmed b. Hanbel, Ebû Abdillâh Ahmed b. Muhammed b. Hanbel eş-Şeybânî. Müsned. thk. Şuayb Arnavut. Beyrut: Müessesetü'r Risâle, 2004. 
Ahmed b. Hanbel, Ebû Abdillâh Ahmed b. Muhammed b. Hanbel eș-Şeybânî. el-Câmiu'l Ulûmi'l İmam Ahmed el-Fıkh. Mısır: Dâru'l Fellâh-i li'l Bühûsi'l İlmiyye, 2009.

Ahmed b. Hanbel, Ebû Abdillâh Ahmed b. Muhammed b. Hanbel eș-Şeybânî. Mesâilü'l Ahmed b. Hanbel Rivayet-ü ibnühü Abdullah. Beyrut: el-Mektebü'l İslâmî, 1981.

Ali el-Medinî, Abdullah b. Cafer el-Medinî. Süelât-ü İbn Ebî Şeybe. Riyad: Mektebetü'l Meârif, 1984.

Aynî, Ebû Muhammed Mahmud b. Ahmed Bedreddin. el-Binâye fî Şerhi'l Hidâye. Beyrut: Dâru'l Kütübü'l İlmiyye, 2000.

Aynî, Ebû Muhammed Mahmud b. Ahmed Bedreddin. Nühabü'l Efkâr fi Tenkîhi'l Mebâni'l Ahbâr. Katar: Vüzârâtü'l Evkâf-i ve'ş Şuûni'l İslâmiyye, 2008.

Beyhâkî, Ebû Bekr Ahmed b. el-Hüseyn b. Alî. es-Süneni'l Kübrâ li'l Beyhakî. Muhammed Abdülkadir Ata. Beyrut: Dâru'l Kütübi'l İlmiyye, 2003.

Beyhakî, Ebû Bekr Ahmed b. el-Hüseyn b. Ali. Ma'rifetü's Sünen-i ve'l Âsar. Abdülmu'tî Emin Kal'acî. Kahire, Dâru'l Vefa, 1991.

Buhârî, Ebû Abdillâh Muhammed b. İsmâîl b. İbrâhim el-Cu'fî. et-Târîhu'l Kebîr. Haydarâbâd, Dâiratü'l Meârifi'l Osmaniyye, t.y.

Buhârî, Ebû Abdillâh Muhammed b. İsmâil b. İbrâhim, el-Câmi'u's-sahîh, nşr. Muhammed Züheyr b. Nasr. y.y: Dâru Tavki'n-Necât, 2. Basım, 1422/2001.

Burhânüddîn el-Buhârî, Mahmûd b. Ahmed b. Abdilazîz el-Buhârî el-Mergīnânî. el-Muhîtü'l Burhânî. Beyrut: Dâru'l Kütübi'l İlmiyye, 2004.

Bûsîrî, Ebü'l-Abbâs Şihâbüddîn Ahmed b. Ebî Bekr b. İsmâîl, Misbahu'z Zücâce fî Zevâid-i İbn Mâce. Beyrut: Dâru'l Arabî, 1403.

Büstî, Ebû Hâtim Muhammed b. Hibbân b. Ahmed el-Büstî. Sahîhi İbn Hibbân. thk. Şuayb Arnavut. Beyrut: Müessesetü'r-Risale, 1414/1993.

Dârekutnî, Ebü'l-Hasen Alî b. Ömer b. Ahmed. es-Sünen. thk. Şuayb Arnavut. 5 Cilt. Beyrut: Müessestü'r Risâle, 2004.

Demirî, Kemaleddin Muhammed b. Musa. en-Necmü'l Vehhac fi Şerhi'l Minhâc. Cidde: Dâru'l Minhac, 2004.

Ebû Dâvûd, Süleymân b. el-Eş'as b. İshâk es-Sicistânî. es-Sünen. thk. Şuayb Arnavut. Dâru'l Risâleti'l Âlemiyye,2009/1430.

Ebû Dâvud, Süleyman b. Eş'as b. İshâk es-Sicistânî. Süelât-ü Ebî Ubeyd el-Âcurrî. Suudî Arabistan: İmâdetü'l Bahsi'l İlmî bi'l Câmiati'l İslâmiyye, 1983.

Ebû Nuaym el-İsfahânî, Ahmed b. Abdillâh b. İshâk. Ma'rifetü's Sahâbe. thk. Âdil b. Yûsuf elAzâzî. Riyad: Dâru'l Vatan-i li'n Neșr, 1998/1419.

Ebû Ömer, Dübyan b. Muhammed. el-Muamelâtü'l Maliyye. Riyad: Mektebetü'l Melik Fahd Vataniyye, 2011.

Ebû Ya'lâ, Ahmed b. Alî b. el-Müsennâ et-Temîmî el-Mevsılî. Müsned. thk. Hüseyin Selim Esed. Şam: Dâru'l Me'mûn, 1984/1404.

Ebû Zür'a, Ubeydullah b. Abdilkerîm b. Yezîd er-Râzî. ed-Duefâ li Ebî Zür'a er-Râzî. Medine: İmâdetü'l Bahsi'l İlmî bi'l Câmiati'l İslâm, 1982.

Elbânî, Ebû Abdurrahman Muhammed Nâsiruddin el-Elbânî, Sahih-i Ebî Dâvud el-Ümm, (Kuveyt: Müessesetü'l Gurâs-i li'n Neşr, 2002.

Elbânî, Ebû Abdurrahman Muhammed Nâsiruddin. Dâifü Süneni't Tirmizî. Beyrut: elMektebetü'l İslâmî, 1991.

Elbânî, Ebû Abdurrahman Muhammed Nasiruddîn. es-Silsiletü'l Ehâdisi'd Daîfe. Riyad: Dâru'l Meârif, 1992.

Elbânî, Ebû Abdurrahman Muhammed Nâsiruddin. İrvâu'l Galîl. Beyrut: Mektebetü'l İslâmî, 1985.

el-Mevsılî, Abdullah b. Muhammed. el-İhtiyâr-u li Ta'lîli'l Muhtâr. Kahire: Matbaâtü'l Halebî, 1937.

Ezrakî, Ebü'l-Velîd Muhammed b. Abdillâh b. Ahmed b. Muhammed. Ahbâru Mekke. thk. Rüşdî Es-Salih. Beyrut: Dâru'l Endülüs li'n Neșr, t.y.

Fâkihî, Ebû Abdillâh Muhammed b. İshâk b. Abbâs. Ahbâru Mekke. Beyrut: Dâru'l Hadar, 1414. 
Hâkim en-Nisâbûrî, Ebû Abdillâh Muhammed b. Abdillâh b. Muhammed. el-Müstedrek. thk. Mustafa Abdülkadir Ata. Beyrut: Dâru'l Kütübi'l İlmiyye, 1990.

İbn Abidîn, Muhammed Emîn b. Ömer b. Abdilazîz el-Hüseynî ed-Dımaşkî. Reddü'l Muhtar alâ Durri'l Muhtâr. Beyrut: Dâru'l Fikr, 1992.

İbn Adî, Ebû Ahmed Abdullāh b. Adî b. Abdillâh el-Cürcânî. el-Kâmil fí Duefâi'r Rical. Beyrut: Kütübi'l İlmiyye, 1997.

İbn Ebî Hâtim, Ebû Muhammed Abdurrahman b. Muhammed. Cerh ve Ta'dil. Beyrut: Dâru'l İhyâ-i Türasi'l Arabî, 1952.

İbn Ebî Hâtim, Ebû Muhammed Abdurrahman b. Muhammed. el-Îlel. y.y: Metâbiu'l Hamîdî, 2006.

İbn Ebî Hâtim, Ebû Muhammed Abdurrahman b. Muhammed. el-Merâsil. Beyrut: Müessesetü'r Risale, 1397.

İbn Ebî Şeybe, Ebû Bekr Abdullāh b. Muhammed. el-Musannef. thk. Kemâl Yûsuf el-Hût. Riyad: Mektebetü'r Rüşd, 1409.

İbn Hacer el-Askalânî, Ahmed b. Ali b. Hacer Ebû Fadl. Itthâfü'l Mehere bi'l Fevâid. Medine: Mucemmâu'l Melik Fahd, 1994.

İbn Hacer el-Askalânî, Ahmed b. Ali b. Hacer Ebû Fadl. Lisânu'l Mîzân. Hindistan: Dâiratü’l Mârifeti'n Nizâmiyye, 1971.

İbn Hacer el-Askalânî, Ahmed b. Ali b. Hacer Ebû Fadl. Tehzîbü't Tehzîb. Hindistan: Matbuatü't Dâirati'l Mearifi'n Nizamî, 1908.

İbn Hacer el-Askalânî, Ahmed b. Alî b. Hacer Ebû Fadl. Fethu'l Bârî, Beyrut: Dâru'l Ma'rife, 1379.

İbn Hibbân, Muhammed b. Hibbân b. Ahmed b. Hibbân. es-Sikât. Hindistan: Vüzerâtü'l Meârif li'l Hükûmeti'l Âliyeti'l Hindiyye, 1973.

İbn Kânî, Ebü'l-Hüseyn Abdülbâkî b. Kâni’ b. Merzûk el-Ümevî el-Bağdâdî. Mu'cemü’s Sahâbe. Medine: Mektebü'l Gurâbâi'l Eseriyye, 1418.

İbn Kesîr, Ebü'l-Fidâ' İmâdüddîn İsmâîl b. Şihâbiddîn Ömer. Câmi'u'l Mesânîd ve's Sünen. Beyrut: Dâru'l Hadr, 1998/1419.

İbn Kudâme, Şemseddin Ebû'l Ferec, Şerhu'l Kebîr, Mısır: Hicr-u li't Tebâati ve'n Neşr ve’t Tevzi' ve'l i'lan, 1995.

İbn Mâce, Ebû Abdillâh Muhammed b. Yezîd Mâce el-Kazvînî. es-Sünen. thk. Şuayb Arnavut. y.y: Dâru'r Risaleti'l Âlemiyye, 2009.

İbn Mende, Ebû Abdillâh Muhammed b. İshâk b. Muhammed el-İsfahânî. Fethu'l Bâb fi'l Künye ve'l Kâb. Riyad: Mektebetü'l Kevser, 1996.

İbn Nüceym, Zeynuddin b. İbrâhim. el-Bahru'r Râik. y.y: Dâru'l Kütübi'l İslâmî, t.y.

İbn Rüşd, Ebû Velid Muhammed b. Ahmed. el-Beyan ve't Tahsîl. Beyrut: Dâru'l Garbi'l İslâmî, 1988.

İbn Teymiyye, Takiyuddin Ebû'l Abbas. Mecmuû Fetâvâ. Medine: el-Mecma' Melik Fahd li't Tebâati Mushafi'ş Şerif, 1995.

İbn Zenceviye, Ebû Ahmed Humeyd b. Muhlid İbn Zenceviye. el-Emvâlü'l İbn Zenceviye. Suud: Merkez-ü el-Melik Faysal li'l Buhûs ve'd Dirasâti'l İslâmiyye, 1986/406.

İbnü'l Cevzî, Cemâleddin Ebû'l Ferc Abdurrahman b. Ali. ed-Duefâ ve'l Metrukûn. thk. Abdullah el-Kâdî. Beyrut: Dâru'l-Kütübi'l İlmiyye, 1985.

İbnü'l Esîr, Ebû'l Hasan Ali b. Ebû'l Kerim. Üsdü'l Gâbe. Beyrut: Dâru'l Fikr, 1994.

İbnü'l Kayserânî, Ebü'l-Fazl İbnü'l-Kayserânî Muhammed b. Tâhir b. Alî el-Makdisî. Ma'rifetü't Tezkire. thk. İmâduddin Ahmed Haydar. Beyrut, Müessesetü'l Kütübi's Sekafiyye, 1985.

Karâfî, Ebû Abbas Șehabeddin Ahmed b. İdris. ez-Zehîra. Beyrut: Dâru'l Garbi'l İslâmî, 1994.

Kasım b. Sellam, Ebü'l Ubeyd. el-Bağdadî. Kitâbü'l Emval. Beyrut:, Dâru'l Fikr, t.y.

Kudûrî, Ahmed b. Muhammed. et-Tecrîd-ü li'l Kudûrî. Kahire: Dâru's Selam, 2006.

Lehmî, Ali b. Muhammed, et-Tebsira. Katar: Vüzerâtü'l Evkâf-i ve'ş Şuûni'l İslâmî, 2011.

Mâverdî, Ebü'l-Hasen Alî b. Muhammed b. Habîb el-Basrî. el-Hâvi'l Kebîr. Beyrut: Dâru'l Kütübi'l İlmiyye, 1999/1419.

Merginânî, Ali b. Ebî Bekir Ebû'l Hasan Burhâneddin. el-Hidâyet-ü fi Şerhi'l Bidâye. Beyrut: Marife 21/2 (2021): 909-934 
Dâru'l İhyâ-i Türâsi'l Arabî, t.y.

Mervezî, Ebû Yakub Mervezî el-Kevsec. Mesâilü'l İmam. Ahmed ve İshâk b. Raheveyh Medine: Îmâdetü'l Bahsi'l İlmiyye, 2002.

Mizzî, Ebü'l-Haccâc Cemâlüddîn Yûsuf b. Abdirrahmân b. Yûsuf, Tehzîbü'l Kemâl fi Esmâi'r Rical. Beyrut: Müessesetü'r Risale, 1980.

Moğaltay b. Kılıç, Ebû Abdillâh Alâüddîn Moğultay b. Kılıç b. Abdillâh el-Bekcerî. İkmâl-ü Tehzîbi'l Kemâl. y.y: Fârûku'l Hadîset-i lit'Tabâa, 2001.

Müslim, Ebü'l-Hüseyn Müslim b. el-Haccâc b. Müslim el-Kuşeyrî. el-Câmi'u's-Sahîh. thk. Muhammed Fuâd b. Abdilbâkî. Beyrut: Dâru İhyâi't-Türâsi'l-Arabî, 1431/2010.

Nesâî, Ebû Abdirrahmân Ahmed b. Şuayb b. Alî. ed-Duefâ-u ve'l Metrukûn. Halep: Dâru'l Va'y, 1976.

Nesâî, Ebû Abdirrahmân Ahmed b. Şuayb b. Alî. ed-Duefâ ve'l Metrukûn. thk. Mahmud İbrâhim Zayid. Haleb: Dâru'l Va'y, 1396.

Nevevî, Ebû Zekeriyya Muhyiddin Yahyâ b. Şerif. el-Mecmu' Şerhu'l Mühezzeb. y.y: Dâru'l Fikr, ts.

Rûdânî, Muhammed b. Muhammed. B. Süleyman. Cem'u'l Fevâid min Câmiu'l Usûl. Beyrut: Mektebet-ü İbn Kesir, t.y.

Taberânî, Ebü'l-Kāsım Müsnidü'd-dünyâ Süleymân b. Ahmed b. Eyyûb, el-Mu'cemü'l Kebîr. Kahire: Mektebet-ü İbn Teymiyye, 1415/1994.

Tahâvî, Ebû Ca'fer Ahmed b. Muhammed b. Selâme el-Ezdî el-Hacrî el-Mısrî. Şerh-u Meâni'l Âsar. Medine: Âlemü'l Kütüb, 1994/1414.

Temimî, Ebû Abdullah Muhammed b. Ali. Şerhu't Telkîn. y.y: Dâru'l Garbi'l İslâmî, 2008.

Yahyâ b. Maîn, Ebû Zekeriyyâ. Târîh-u İbn Maîn. Şam: Dâru'l Me'mun-i li't Turâs, t.y.

Yahyâ b. Maîn, Ebû Zekeriyya. Min Kelam-i Ebû Zekeriya. Şam: Dâru'l Me'mun-i li't Türâs, t.y.

Yahyâ b. Maîn, Ebû Zekeriyya. Târîh-u İbn Maîn. Mekke: İhyâu't Türâsi'l İslâmî, 1979.

Zehebî, Ebû Abdillâh Șemsüddîn Muhammed b. Ahmed b. Osmân. Divânü'd Duefâi'l Metrukîn. Mekke: Mektebetü'n Nahdati'l Hadîse, 1967.

Zehebî, Ebû Abdillâh Şemsüddîn Muhammed b. Ahmed b. Osmân. el-Ma'na fi'd Dûefâ. y.y: Mektebetü'ş Şamile, t.y. 